Portland State University

PDXScholar

Fall 1-4-2017

\title{
Out in "The Numbers": Youth and Gang Violence Initiatives and Uneven Development in Portland's Periphery
}

Dirk Kinsey

Portland State University

Follow this and additional works at: https://pdxscholar.library.pdx.edu/open_access_etds

Part of the Geography Commons

Let us know how access to this document benefits you.

\section{Recommended Citation}

Kinsey, Dirk, "Out in "The Numbers": Youth and Gang Violence Initiatives and Uneven Development in Portland's Periphery" (2017). Dissertations and Theses. Paper 3365.

https://doi.org/10.15760/etd.5256

This Thesis is brought to you for free and open access. It has been accepted for inclusion in Dissertations and Theses by an authorized administrator of PDXScholar. Please contact us if we can make this document more accessible: pdxscholar@pdx.edu. 
Out in "The Numbers":

Youth and Gang Violence Initiatives and Uneven Development in

Portland’s Periphery

by

Dirk Kinsey

A thesis submitted in partial fulfillment of the requirements for the degree of

\author{
Master of Arts \\ in \\ Geography
}

Thesis Committee:

Barbara Brower, Chair

Hunter Shobe

Nathan McClintock

Portland State University

2016 
(C) 2016 Dirk Kinsey 


\begin{abstract}
Incidence of youth and gang violence in the Portland, Oregon metro area has increased dramatically over the past five years. This violence has recently become more spatially diffuse, shifting outwards from gentrified, inner city neighborhoods, towards the city's periphery. These incidents exist within the context of a shifting regional political economy, characterized by a process of gentrification associated displacement and growing, and distinctly racicalized and spatialized, inequalities. While gang researchers have long argued a corollary between the emergence of gangs and economically and culturally polarized urban landscapes, the ongoing suburbanization of poverty in American cities suggests a new landscape of uneven power differentials playing out between disenfranchised youth and those seeking to police and prevent violence. This paper provides a critical examination of how local agencies charged with addressing youth and gang violence are responding to shifts in the landscape of violence and navigating the inequitable distribution of wealth and resources in the "progressive" city. Drawing on interviews conducted with police, policy makers and gang outreach workers, I investigate both perceptions of gentrification's role in youth and gang violence and the spacialities of emerging enforcement and prevention efforts. My findings suggest that prevention and enforcement efforts frequently rely on techniques and models designed to replicate conditions in older, gentrified neighborhoods, while perhaps unwittingly reifying existing inequalities. Ultimately, I hope to reveal some of the links, both at macro-
\end{abstract}


structural levels and those of daily practice, between a shifting political economy and emerging forms of suburban policing. 


\section{Dedication}

This thesis is dedicated to those who have lost their lives to youth and gang violence in Multnomah County and to the families and communities who continue to live with those losses. 


\section{Acknowledgements}

Many people have helped bring this project to fruition. Firstly, I must acknowledge the support of my family through my schooling. They have, and continue, to encourage me on this path that I have chosen for myself, regardless of how long and circuitous it may be. Dr. Barbara Brower has been immensely patient and supportive in this process and has always provided me with thoughtful and challenging feedback. Without her this project would have never seen the light of day. Dr. Hunter Shobe has always taken the time to offer feedback and guided and supported me through the writing process. Dr. Nathan McClintock served to push me in directions that challenged my pre-conceptions and deepened my analysis at every turn. I am extremely thankful to all of them. 
Table of Contents

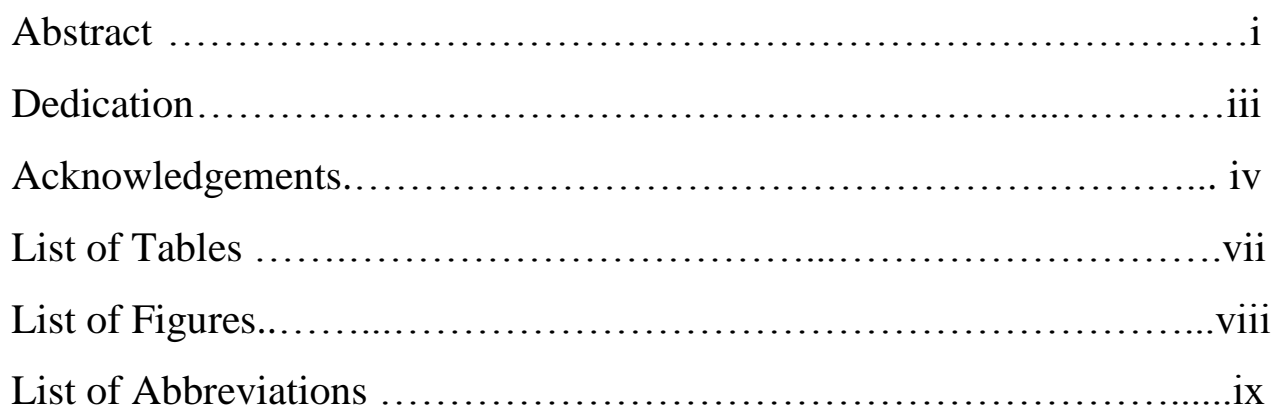

Introduction..................................................

Chapter I: Understanding Gangs in Context..........................10

Defining Gangs...................................................... 10

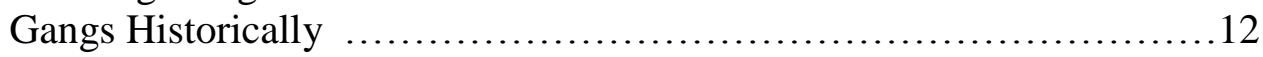

The Growth of US Gangs in the Twentieth Century............................ 14

The Emergence of West Coast Gangs............................ 15

Gangs and the Contemporary Urban Context........................ 22

Chapter II: Gangs and Geographies of Urban Inequity....................25

Why are there gangs?............................................. 25

Social Disorganization ..........................................26

The Adaptation Model ...........................................27

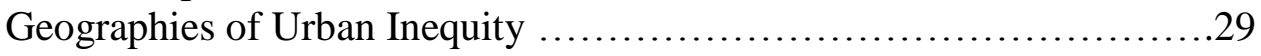

Uneven Development .........................................30

Restructuring of Urban Economics and Governance ..................32

Planning Histories ................................................36

Chapter III: Chapter 3: Policing and Social Service Provisions ...........38

Geographies of Policing .......................................40

Social Service Provisions, "The Shadow State",

and Local Governance............................................45

Chapter IV: Geographies of Poverty and Race, and the Emergence of Gangs in Multnomah County ....................................48

Multnomah County's Gang Geographies as Geographies

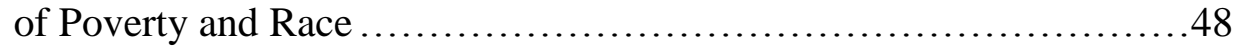

Albina........................................................48

The Columbia Villa Projects .......................................51

East Portland \& Gresham ...............................................53 
The Emergence of Gangs and Gang Control in Multnomah County.....55

Chapter V:Findings .............................................62

County and Municipal Institutions................................63

Social Service Providers..........................................65

Law Enforcement.............................................66

Coordination and Collaboration....................................68

Coordination and Collaboration, and the Improved Ability

to Provide Services............................................71

Coordination and Collaboration as Spatial Control ....................72

Community Participation ...........................................75

Discussion ......................................................... 80

Relocation....................................................... 82

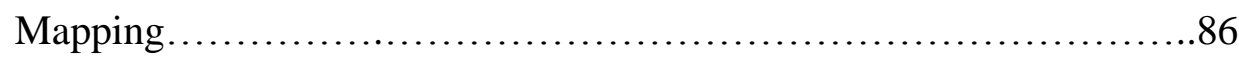

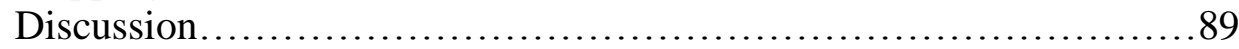

Perceptions of Gentrification......................................91

Disruption of Violence Prevention Efforts ........................992

Disruption of Existing gang Structures ............................. 94

Disruption of Neighborhood Social Structure.......................96

Discussion..............................................97

Chapter VI: Conclusion............................................ 100

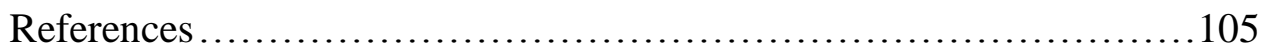

Appendices

A. Methods.....................................................115

B. Multnomah County Gangs as listed in the Multnomah County

Comprehensive Gang Assessment, 2014...........................122

C. Human Subjects Review Approval .............................124 


\section{List of Tables}

Table 1. Service Providers Mentioned by Respondents.................83 


\section{List of Figures}

Figure 1. Density of "Shots Fired" Calls for Service in

Multnomah County .............................................2

Figure 2. Enough is Enough PDX Billboard...........................78 
List of Abbreviations

EMGET East Multnomah Gang Enforcement Team

FBI Federal Bureau of Investigation

GET Gang Enforcement Team

GIFT Gang Impacted Families Team

GRIT Gang Resource Intervention Team

JJD Juvenile Justice Department

LPSSC Local Public Safety Coordinating Council

OJJDP Office of Juvenile Justice and Delinquency Prevention

OYVP Office of Youth Violence Prevention

POIC Portland Opportunities Industrialization Center

PPB Portland Police Bureau

RENEW Rockwood/Rosewood Enrichment Neighborhood Enforcement

Workgroup

SACSI Strategic Approaches to Community Safety Initiative, locally know, as STACS

SLGOW Street Level Gang Outreach Workers

STRYVE Striving to Reduce Youth violence Everywhere

ICE U.S. Department of Homeland Security-Immigration and Customs

Enforcement

YGSF Youth Gang Strike Force 


\section{Introduction}

The headline of the May 30th, 2015 Oregonian puts into sharp relief a dynamic that has been bubbling just below the surface of public awareness in Portland: "Last Thursday shootings: At the epicenter of Portland's changes, tensions between old and new, residents and tourists" (Park 2015, n.p.). The shooting, at a popular outdoor arts event in Northeast Portland, on what has been regarded as a thoroughly gentrified street, NE Alberta, came as a surprise. The shooter, a teenager who lived in neighboring suburb, but with family ties to the neighborhood, was sixteen years old. He fired at a stranger who, he would later state, he thought was "eying him" (Park 2015,n.p.), missing him and hitting two fifteen-year-old boys and a twenty-five-yearold woman. The "tensions" in the title were manifested in the actions of customers at an upscale ice cream parlor. Images of couples taking selfies with police tape in the background and the vocal complaints of patrons over the police's insistence that the business close shop temporarily became the fodder for social media indignation (Park 2015). These responses reflected ambivalence to the lives of those involved in the shooting and a perceived lack of historical context. This incident became an illustration of the way in which the gains of gentrification had not been experienced evenly throughout the community. 


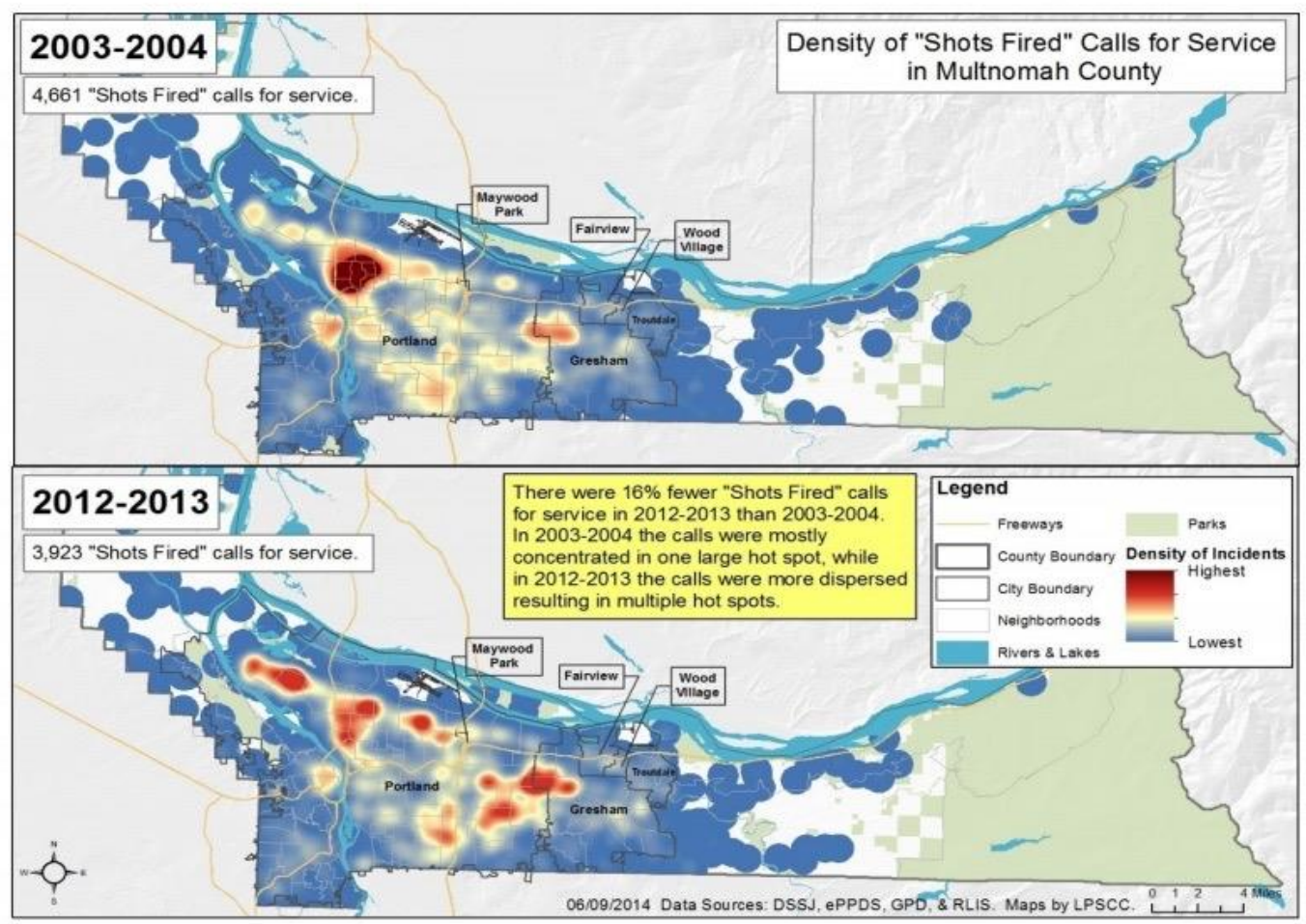

Figure 1. Density of "Shots Fired" Calls for Service in Multnomah County (Local Public Safety Coordinating Council 2014)

Nearly a year later a second shooting provides further insight into violence plaguing the Portland area: A birthday party at the Rosewood Initiative Community Center was interrupted by gunfire wounding four people. Nearly two dozen shots were fired and a 15-year-old girl taken to the hospital by ambulance while three men, ages 20,17 , and 19 would later arrive at hospitals scattered throughout the metro region (Hernandez 2016). The Rockwood neighborhood in which the shooting took place straddles the border of Portland and the neighboring city of Gresham, an area that has recently become associated with increasing levels of concentrated poverty and an ethnically and linguistically diverse population. It has become home to many of those displaced by the rising housing prices in inner North and North East Portland. 
These incidents and others like them have been attributed, whether correctly or not, to what is seen as a growing trend in youth and gang violence in Multnomah County, Oregon. Despite Portland's history of youth and gang violence dating back to the 1980's, the common assumption held by authorities and residents has been that the redevelopment of inner city neighborhoods and an improved economic climate meant that the days of gang violence were gone (VanderHart 2013). In some ways this rings true; gang violence in Portland and Multnomah County significantly decreased since its peak in the late 1990's, and has undergone a significant spatial redistribution. In Portland, gang-associated violent crime peaked in 1995 with more than 300 shootings, then decreased steadily till 2007 , a year with fewer than twenty shootings (VanderHart 2013). This decrease was significant enough to cause the Portland Police Bureau to eliminate a gang-specific patrol unit in the early 2000's (VanderHart 2014). In recent years, however, Multnomah County has experienced a growing incidence of youth and gang violence. Between 2007 and 2015, the Portland Police Bureau reported a 522\% increase in violent crimes classified as gang-related, with an average increase of 20.25 incidents per year (VanderHart 2013) ${ }^{1}$. This longterm decrease and recent uptick is shared by national gang violence statistics, suggesting that this is a local manifestation and part of a wider trend (National Youth Gang Survey Analysis 2014). Contrary to historical patterns, recent activity has been largely located outside of Portland's inner city neighborhoods. Portland's gangs have

\footnotetext{
${ }^{1}$ These statistics should not necessarily be taken at face-value. Designations of "gang" crimes are notoriously problematic and frequently subject to manipulation. This is discussed further in Chapter 1.
} 
historically been active in North and inner Northeast Portland, an area known for high levels of residential segregation and concentrated poverty. However, gang violence has recently had an increased presence in outer Northeast and Southeast Portland, as well as the neighboring suburb of Gresham, with increasing signs of gang graffiti, youth recruitment, assaults and homicides (VanderHart 2014; Hall 2014).

In many ways, growing youth and gang violence runs contrary to the Portland area's progressive image. The city's reputation for progressive politics, innovative urban planning, environmental sustainability, and the elusive concept of "livability" (Ozawa 2004) has served to create an image of Portland as one free from many of the issues traditionally associated with urban areas: crime, concentrated poverty, and residential segregation. This image has a powerful appeal, especially for younger, more affluent populations attracted to the city's amenities. Portland, like many U.S. cities, has experienced a significant population increase. From 2000 to 2010, Portland's population increased by more than 54,000 residents (Population Research Center 2011). Population estimates from 2013 show Portland gaining roughly 26,000 residents since the 2010 decennial census (American Community Survey 2013). Similarly, the Portland Metro region has seen significant overall economic gains, with an increase of 70,000 jobs between 2010 and 2013, replacing jobs that were wiped out during recession of 2008 (Kaylor 2014).

However, Portland's gains in the form of greater economic growth and environmental sustainability have not been shared by all. Roughly seventeen percent of Portland residents and twenty-two percent of children live below the poverty line 
(Goodling, Green and McClintock 2015). For Non-Whites, this poverty is especially pronounced. Median household income for Blacks and Latinos ranges from half to a third of that of White households while more than a third of the city's Black population lives below the poverty line, and (Goodling, Green and McClintock 2015).

As in Metro areas throughout the US, the geography of poverty in Multnomah County has altered in the past decade; the number of people living in poverty in Portland's suburbs increased by ninety-nine percent between 2000 and 2011 (Hagerty 2014). Housing prices within inner city neighborhoods have risen precipitously in the past fifteen years, leading to a pattern of displacement of low-income residents and communities of color. From 2000 to 2010, thirty eight census tracts within Portland became whiter, with an out-migration of nearly 10,000 people of color, mostly African Americans (Hannah-Jones 2011). Of those who left, many settled on the city's eastern edges where access to services like public transit and amenities such as parks even basic infrastructure in the form of sidewalks is comparatively limited (Hannah-Jones 2011). Within city limits, poverty increased by more than seventy-one percent, much of it emerging in East Portland (Kneebone and Williams 2013).

The accounts of those involved with youth violence initiatives in Multnomah County suggest a correlation between the gentrification of the inner North and North East neighborhoods and the expansion of gang activity eastward. Gentrification and its related displacement have become the favored explanation for these shifts amongst gang out-reach workers and police (Vanderhart 2013; Bernstien 2014). While gang researchers have long argued a connection between gangs and economically and 
culturally polarized urban landscapes (Hagedorn 2007) the ongoing gentrification and suburbanization of poverty in American cities suggests a new landscape of uneven power differentials playing out between disenfranchised youth and those seeking to police and prevent violence. The form of American cities has been profoundly affected by a shift towards systems of neoliberal governance as have the philosophies and practice of policing and violence prevention. Neoliberal restructuring then binds violence prevention efforts and the urban form itself.

The focus of this thesis is the shifting geographies of youth and gang violence in Multnomah County and the efforts at the prevention of that violence. I seek to contextualize these emerging prevention strategies within an urban political economy characterized by a gentrifying inner-city and rising levels of poverty in suburban settings. In order to do so I ask, how have violence prevention strategies adapted to new geographies of poverty in Multnomah County? How do perceptions of gentrification and displacement inform these prevention efforts? And finally, how might these efforts themselves contribute to emerging socio-spatial configurations?

The first chapter provides an overview of the history and development of contemporary American gang culture. The story of American gangs is closely aligned with the story of American cities themselves. I argue that shifting macroeconomic and social conditions have manifested in distinct urban forms and produced conditions that have fostered the development, maintenance, and proliferation of gangs. This chapter also looks closely at economic and social marginality, a consistent theme throughout the history of gang research. I review both the ways in 
which gang theorists have understood the role of spatialized inequalities in the development and proliferation of gangs, and how urban inequality has been understood within contemporary geographic research, emphasizing Marxist theorizing, Post-Fordist economic restructuring, and the role of local planning initiatives in producing uneven and racialized urban geographies. Responses to gang violence in Portland and many other US cities have been holistic, integrating the efforts of law enforcement and service providers. In order to understand how responses to gang violence may have adapted to processes of gentrification and displacement, chapter two provides an overview of recent work in geography and related fields about the functions and practices of the police and social services; I emphasize the dramatic impact by neoliberal restructuring on these institutions.

The third chapter situates the processes associated with urban inequality and gang development in the local context. I begin by examining the origins and transformation of Multnomah County's geographies of racialized poverty. This is followed by an account of the emergence of gang violence within Multnomah County during the 1980's and early efforts at preventing and of policing that violence.

The final chapters cover the findings of my own research into gang violence prevention strategies in Multnomah County. I'm drawing largely on qualitative methods, including participant observations at community and stakeholder meetings and eleven semi-structured interviews with Police, policy makers and outreach workers. Additional source material includes media and policy documents. 
Gang research has historically focused on the development and structure of gangs themselves and more recently on the efficacy of various strategies for preventing gang violence (Sheldon, Tracy, and Brown 2013). This paper does not directly contribute to that body of literature, but rather draws from it in order to contextualize the emergence of gangs and gang violence prevention within Multnomah County. Previous work pertaining to the geographies of policing and social service provisions has emphasized the role of these institutions in the as a means through which state power exerts and legitimizes its control. However, there is little work within geography that looks at the integration of these two facets of urban governance. In my case study, policing and social service provisions are understood to be points on a continuum of gang violence prevention, integrated practically and theoretically.

This thesis, then, contributes to the geographic literature on urban governance and policing in multiple ways. It first seeks to understand ways in which strategies of gang violence prevention has adapted to a spatial redistribution of violence. These adaptations shed light not only on how violence and crime are addressed but the ways in which poverty in suburban settings is countered. Secondly, it looks at perceptions of the impact of gentrification and displacement on youth and gang violence. These perspectives help inform our understanding of how the issue is conceptualized by practitioners and policy makers. Finally, it seeks to draw connections between these strategies and the macro-level phenomena that have produced the specific patterns of violence now being addressed. 
Multnomah County has been unable to avoid many of the larger systemic issues that have negatively impacted the rates and spatialization of urban poverty. Portland's political economy, like that of most American cities, fosters the growth of its most prosperous neighborhoods to the detriment of marginalized communities. Local governments cater to business interest and the increasingly affluent families that support the tax base of the city. The end result can be disproportionate police manpower and investment in education, recreation, and transportation in upscale neighborhoods rather than the places that need these resources the most. These areas of need in the Portland metro are more and more the peripheral suburbs, away from their increasingly affluent city center.

It is worth noting that in the specific case of Multnomah County, the communities who have largely borne the brunt of the unequal outcomes of gentrification are also the communities most affected by youth violence. The spatial redistribution of youth and gang violence represents a challenge to police and social service providers tasked with adapting to these shifts and a disproportionate burden on communities already subject to social and economic marginalization. 


\section{Chapter I: Understanding Gangs in Context}

\section{Defining Gangs}

There is little consensus on what constitutes a gang, a gang member, or gang crime. Eight decades of research on gangs has yielded no definition shared by the majority of researchers or gang-prevention specialist (Ball and Curry 1995; Klein 1969; Klein and Maxson 2006; Miller 1975; Needle and Stapleton 1983). Within gang research, definitions have typically emphasized some combination of youthfulness, criminality, organization, territoriality, violence, street-orientation, and group identity. Frequently cited definitions from Thrasher (1927), Klein (1969), Miller (1980) all emphasizes these characteristics to a greater or lesser degree. The conflict among competing definitions is generally in the degree to which one facet is emphasized over another (Sheldon, Tracy, and Brown 2012).

The lack of a clear definition is, of course, problematic for both gang-related research and the practices of gang control. The National Youth Gang Center, on behalf of the U.S. Department of Justice, conducts annual surveys of police and sheriff's departments about local gang populations in order generate a national estimate. The survey has historically relied on law enforcement to identify gang members based on their own criteria, producing wildly inflated estimates of gang membership. In the 1996 survey, 58\% of respondents included "taggers" and 20\% included "stoners" in their estimates (Klein and Maxson 2006). Inversely, groups who 
may fit many of the criteria associated with gangs are frequently excluded from standard definitions. $^{2}$

More useful is to consider the many ways in which gangs are understood and defined by those who seek to address the issue. Moore's list of common gang stereotypes illustrates the ways in which these groups are commonly understood:

"(1)They are composed of males (no females) who are violent, addicted to drugs and alcohol, sexually hyperactive, unpredictable, and confrontational; (2)They are either all African-American or all Hispanic; (3) They thrive in inner-city neighborhood where they dominate, intimidate, and prey upon innocent citizens; (4) They all deal heavily in drugs, especially crack cocaine; (5) "A gang is a gang is a gang" in other words, they are all alike or "you see one and you see them all";(6) There is no good in gangs, it is all bad (a corollary to this is that anyone who would want to join a gain must be stupid or crazy);(7) Gangs are basically criminal enterprises and that youths start gangs in order to collectively commit crimes; in other words, there is a tendency to confuse individual and group criminality; (8) The "West Side Story" image of aggressive, rebellious, but nice kids has been replaced in recent years by the "gangster image of a very disciplined criminal organization complete with "soldiers" (1993:28-29).

Assumptions and stereotypes implicit within definitions are problematic not only research but policy implementation as well. In Multnomah County, active debates about the nature of gangs inform many of the conversations around policing and violence prevention. The Multnomah County Gang Assessment points out that "law enforcement agencies in Multnomah County do not have an accurate method of identifying gang-involved people" (Vanderhart 2015, n.p.). Despite a clear or

\footnotetext{
${ }^{2}$ Venkatesh (2003) notes that college fraternities fit many of the criteria normally associated with gangs (youthfulness, organization, self-recognition, durability and implicit or explicit emphasis on social and or legal transgression), but due to their race and social status, would be unlikely to be considered gangs.
} 
transparent methodology, law enforcement in Multnomah County frequently designates crimes such as shootings, even those without a clear perpetrator or victim, as gang related (Jaquiss, Mesh, and Willson 2014, n.p.). Sheldon, Tracy and Brown point out that the power to designate crimes as gang-related affords law enforcement the ability to shape statistics to meet their needs. ${ }^{3}$ This lack clear methodology may also contribute the disproportionate policing of young men of color. Jo Ann Hardesty, the president of the Portland chapter of NAACP suggests that a gang designation is "a catch-all for any shooting where you think the suspect is black," (Vanderhart 2015, n.p.). Given these definitional uncertainties, questions need to be asked concerning how implemented and how implicit biases may be inform the structure and implementation of gang violence prevention strategies.

\section{Gangs Historically}

Youth groups known as gangs are by no means a phenomenon of the Twentieth Century, nor are they distinctly American. They are, however, a long-standing component of urban social life, their history paralleling that of urbanization itself. Scholars have identified gangs as facets within early Roman society and the citystates of Renaissance Italy, in both cases sometimes deployed as proxies by conventional state actors to further political gains through rougher means (Davis

\footnotetext{
${ }^{3}$ The Portland Police Bureau is currently struggling with staffing issues. It lost 100 full-time employees between 2011 and 2016 (Bernstein 2016). A perceived increase in gang violence could potentially legitimize calls from police for increased funding.
} 
1992). Similar groups were part of the urban life of fourteenth and fifteenth century London, committing robberies and violent crimes and fighting pitched battles with the city watch and among themselves (Hagedorn 2008).

In the United States, delinquent youth groups began to emerge in the nineteenth century in tandem with the expansion of urban capitalist economies and the subsequent mass migrations from Europe (Sante 1991). These early American gangs were formed by two distinct periods of immigration: the "old immigrants" of Western Europe and Britain who arrived between American Independence and roughly 1860 and the over-lapping second group from Ireland, Eastern and Southern Europe, from roughly 1820-1920.

The first era was characterized by the dominance of ethnic Irish gangs on the Lower East Side of Manhattan. These were not explicitly criminal groups; rather, they were generally made up of laborers who engaged in violence as a part of the normative political life of ethnically contested neighborhoods (Sante 1991). Gangs were the "basic unit of social life among the young males in New York in the nineteenth century"(Sante 1991, 198). ${ }^{4}$

Between 1860 and 1910, twenty three million immigrants entered the United States (Trattner 1994). In the later part of the nineteenth century, Irish gangs in New York would be joined by gangs born of successive waves of immigrants packed into

\footnotetext{
4 "As a social unit, the gang closely resembled such organizations as the fire company, the fraternal order, and the political club, all of these formations variously overlapped" (Sante 1991, p.197-198)
} 
impoverished tenement communities: Italian, Jewish, Scandinavian immigrants along with Scot-Irish, Irish Catholic, and Germans (Shelden, Tracy and Brown 2013) (Howell and Moore 2010). Jacob Riis famously documented these areas. The built environment he described as “dark, damp basements, leaking garrets, shops, outhouses, and stables converted into dwellings" (1969, 12, quoted in Howell and Moore 2010,4). This period saw the growth in numbers, sophistication, and violence of many European American gangs, along with a shift from territorial disputes to ethnic conflict and greater criminal activity ${ }^{5}$. Similarly, during this era, Chinese gangs, most notably the Tongs, began to emerge, occupying a gray area between fraternity and criminal organization (Howell and Moore 2010).

\section{The Growth of US Gangs in the Late Twentieth Century}

Gangs in the twentieth century are best characterized by their expansion and diversification. The pre-war period saw the emergence of gangs outside of north eastern cities, as well as the formation of gangs in African American and Latino communities as those groups grew in prominence within Midwestern and western cities.

\footnotetext{
${ }^{5}$ Many of these early American street gang were in fact the progenitors of what we now know as the Mafia (Howell and Moore 2010). However, there are many structural differences between street gangs and organized crime and directly linking the two is problematic.
} 
In the Midwest, Chicago gangs blossomed with the arrival of European immigrants, mostly poor Irish, Polish, and Italian youths. Many of these gangs developed into neighborhood "athletic clubs" which were, in fact, a pseudo-political force bridging the gap between street gangs and the Chicago patronage system (Hagedorn 2008). ${ }^{6}$ During this period, Chicago was also the site of the first major study of gang life, Fredric Thrasher's The gang: A study of 1,313 gangs in Chicago (Thrasher 1927), which provided the foundational theory for a century of gang studies. However, Thrasher was detailing a disappearing world, and within a generation, the gangs of European immigrant youth would be fully assimilated into the social and political mainstream of American life (Hagedorn 2008). For the swelling ranks of young Blacks and Latinos migrating to cities in the North and West, this integration would not be so easily achievable.

\section{The Emergence of West Coast Gangs}

In Los Angeles, two different migrations would contribute to the development of the largest and most prominent gang systems in the country. The growth of an expansive industrial economy in Southern California attracted both Mexicans and African Americans from primarily poor rural communities beginning in the 1920s. Both of these groups would encounter an urban environment and social system radically

\footnotetext{
${ }^{6}$ As Hagedorn (2008) points out, Mayor Richard J. Daly began his rise through the ranks of Chicago politics, first as a member of the Hamburg Athletic Association which likely had a role in the street battles of the 1919 Chicago Race Riots.
} 
different from the one that they had known and strong resistance to their presence from a White establishment (Sheldon, Tracy and Brown 2013).

Between 1910 and 1920, Los Angeles's Mexican population grew from 5,000 to more than 30,000; by 1930 that figure had more than tripled (Romo 1983). This influx was in part due to the political and social instability in Mexico during the period of the Mexican Revolution and the post war reconstruction. While many of these migrants initially planned to return to Mexico, the economic stability offered in the United States and the increased difficulty in returning to Mexico, incentivized many migrants to settle in the Los Angeles area (Romo 1983). Many young Mexican males drawn to the opportunities for employment in Los Angeles brought with them a tradition known as "palomilla" (in Spanish "a convoy of doves"), in which young men would group together by cohort. In Los Angeles, these groups began to identify with particular neighborhoods or areas, becoming what was known as "boy gangs" a precursor to the modern Chicano gang (Sheldon, Tracy \& Brown 2012).

Vigil (2010) identifies a process of systemic marginalization through which Mexican and Chicano youth became susceptible to gang life, a process he calls "choloization" whereby cultural changes and conflicts have made Chicano youth particularly susceptible to gang life (Vigil 2010). This marginalization took two specific forms which would help bring youth together and transform informal groupings into gangs: repatriation and racial violence directed at Mexican youths (Vigil 2010). Residents of Mexican descent were unwilling repatriated during the great depression, a policy that was based in growing racialized fear of Mexicans and 
efforts on the part of the Hoover administration to shift blame for the economic depression. By 1935, some 500,000 people nationwide would be repatriated, with the majority from Los Angeles (Romo 1983). At the same time, a system of wide spread discrimination both informally, and within city and state policy, emerged. This discrimination would culminate with the infamous Zoot Suit riots of 1943, in which marauding bands of white sailors attacked Mexican youth indiscriminately, as well the Sleepy Lagoon trial of 1942, in which 12 Chicano gang members were convicted of murder by what was widely understood to be a racially biased 'kangaroo court' Mexican youth reacted to exclusionary policies and racial violence by creating protective and supportive social institutions in the form of street gangs. These gangs, and those that arose up in their wake, continue to thrive thought out Los Angles and the West (Vigil 2010).

Despite emerging a generation later, Black gangs in Southern California share a similar history of migration and racial discrimination. Like their Mexican counterparts, Blacks in Los Angeles had mostly come from rural communities in the South, attracted to high-paying jobs in the aerospace, automotive and construction sectors (Sheldon, Tracy and Brown 2013;Vigil 2010). Between 1940 and 1970, the Black population of Los Angeles grew from 63,744 to 736,000. These communities were concentrated primarily in areas south of downtown Los Angeles (later referred

\footnotetext{
${ }^{7}$ The presiding Judge allowed testimony from the chief of Los Angeles Sheriff offices Foreign Relations Bureau in which he testified that Mexicans as a community had a "blood thirst" and a "biological predisposition" to crime and killing, citing human sacrifices practiced by their Aztec ancestors (Stacy 2002)
} 
to simply as South Central) and the San Fernando Valley (Davis 1992). However, Blacks in Los Angeles would encounter systemic racism at nearly every turn.

Discrimination in housing, employment, and education, along with increasing police repression and brutality would all contribute to the disenfranchisement of Black youth and ultimately ignite the rebellion widely known as the Watts Riots of 1965.

Like the Zoot Suit Riots, the Watts Riots would change the way that young Black men understood themselves within a white society. The Watts Riots were a moment of political radicalization for many Black youths and in the years following, Black gangs throughout Los Angeles seemed to re-orient towards "the generational awakening of Black Power" (Davis 1992, 296). Black gangs that had emerged over the previous decade and typically engaged in low level "rumbling" amongst themselves over turf, were seen cooperating as they pushed through police lines during the rebellion in Watts ${ }^{8}$ (Davis 1992). The Black Panther organization, with its origins in the San Francisco Bay Area, brought to civil rights a revolutionary romanticism and emphasis on community autonomy that was not lost on gang members. However, the dismantling of the Panthers brought about by the FBI's notorious COINTELPRO program of surveillance and disruption of domestic political organizations, left a vacuum in the cultural and political life of Black youth into which street gangs would once more emerge (Cureton 2008; Davis 1992; Sheldon, Tracy and Brown 2013).

\footnotetext{
${ }^{8}$ For a contemporary example of this kind of collaboration, see the "truce" between Crips, Bloods and Black Guerilla Family during the 2015 Baltimore uprising (Woods 2016).
} 
With many political leaders imprisoned, marginalized or dead, Black youth became increasingly disenfranchised and the number of street gangs once again increased (Sheldon, Tracy and Brown 2013). During the time, arguably the two most influential gangs in US history would emerge, the Crips and the Bloods. Sometime in the late 1960's or early 1970's, Raymond Washington and Stanley “Tookie" Smith founded the Crips. ${ }^{9}$ Washington had been influenced by Panthers and in its early days the Crips operated as a combination neighborhood defense and social service organization (Davis 1992; Sheldon, Tracy and Brown 2013). Crip sets (individual groups under a single Crip umbrella) spread rapidly throughout South Central in the early 1970's. This expansion forced existing independent gangs such as the Brims, Bounty Hunters, Denver Lanes, Athens Park Gang, the Bishops and the now notorious Pirus into a federation (Davis 1992; Vigil 2010). The Bloods were born then as a decidedly defensive reaction to the explosive growth of the Crips. In 1972 saw 29 gang homicides in South Central Los Angeles. By 1974 that figure would more than double (Shelden,Tracy and Brown 2013).

As violence between Bloods and Crips was ramping up, the manufacturing economy that had sustained Black and Chicano workers, albeit to a limited degree, was falling apart. For North American cities, deindustrialization meant both the disappearance of jobs and the spatial transformation of the city itself. The Fordist centers of mass production in the United States (Chicago, Detroit, Los Angeles)

\footnotetext{
${ }^{9}$ The origins of the "Crip" name are too apocryphal and numerous to even address though both Davis (1992) and Shelden,Tracy \& Brown (2013) offer fascinating and sometimes conflicting narratives.
} 
began to see large corporations decentralizing their operations outside of their urban cores and a deterioration of the built environment of inner city neighborhoods (Anderson and Wilson 2004). Into this environment crack cocaine would be introduced, devastating inner-city communities and providing a new kind of menial labor for young men of color. Gangs in Los Angeles became increasingly involved in the drug trade, though perhaps not to the degree that has been assumed in media portrayals of gang life (Shelden,Tracy and Brown 2013).

Today, the LAPD estimates that there are more than 250 gangs with more than 26,000 gang members in Los Angeles. Black and Chicano gangs have been joined by South East Asian, Pacific Islander, and most notably Central American groups (Shelden,Tracy and Brown 2013). I have chosen to emphasize the history of gangs in Los Angles over the equally rich and complex post-war gang landscape of Chicago and New York because of the direct relation to the gangs of Portland. Dominate among the dozens of reported sets in Multnomah County are Crips, Bloods and Hoover Criminals (an early off shoot of Crips), along with Sureno and Norteno sets (Multnomah County, 2014) which in many ways are the heirs, not the direct descendants, of the Chicano gangs of earlier periods. It is also these Los Angelesbased groups, who through their proximity to a centralized entertainment industry have come to dominate media representations of gang life. Films such as Colors (1988), Boyz in the Hood (1991), Menace II Society (1993) along with countless television programs and, of course, the once ubiquitous gangsta rap, have not only contributed to the broad dissemination of depictions of gang life but have also 
fostered widespread and racialized moral panics among a dominate class, both terrified of and titillated by these stories (Shelden, Tracy and Brown 2013).

The longevity of Los Angeles gangs is also important in understanding contemporary gang life. Hagedorn argues that the success and dissemination of Los Angeles gangs is the result of a process of gang "institutionalization" (Hagedorn 1991, 2008). Institutionalization can be understood less a centralization of authority within the gang, but rather a persistence of the organization and its values and symbols through multiple generations of members (Hagedorn 2008). Most gangs in fact do not institutionalize and remain relatively disorganized only to quickly dissolve. Hagedorn suggest that the conditions for institutionalization (namely advanced social marginality and spatial exclusion) do not exist in all cities and therefore institutionalization is a process that is experienced unevenly across space (Hagedorn 2008) $^{10}$.

The gangs of Los Angeles then are important to this study not only as the progenitors of Portland's gangs, but also a representative of way in which localized conditions may produce a gang culture that persists for multiple generations.

\footnotetext{
${ }^{10}$ New York is an example of a city that does not currently have institutionalized gangs. Hagedorn (2008) argues that this is the result of the combination of specific social policies instituted in the 1960s at the municipal level and the introduction of hip-hop culture by former gang members as an alternative to violence.
} 


\section{Gangs and the Contemporary Urban Context}

Despite the historical and local variances, gangs in the United States over the past 200 years largely emerged within the context of the industrial city. Immigration and migration, along with the spatial divisions associated with the ascent and decline of urban industrial economies have fostered the formation, maintenance, and proliferation of gangs. However, in many ways cities have fundamentally changed over the past four decades, with important shifts in the economics, culture and governance impacting the form and functions of urban areas. As Shelden, Tracy and Brown (2013) point out, contemporary gangs may not be structurally different from their historic counterparts, rather the expanded role of violence and criminality in gang life may be a reflection of changing macroeconomic and social conditions. To this point, examining the current state of gangs requires an examination of the changing nature of urbanism itself. Hagedorn (2007) identifies three major impacts of globalizing cities for theorizing contemporary gangs; (1) the rise of the so-called "post-industrial" or information economy, (2) mass incarceration and (3) spatial exclusions associated with urban agglomeration and gentrification.

The shift from an industrial to a service/information economy, with its corresponding requirements for advanced education a training, has meant the exclusion of millions of young people of color from mainstream economies over the past four decades (Shelden,Tracy and Brown 2013). The growth of gangs can in part be understood as a response to this shift, in which gangs have become institutionalized (Hagedorn 1991/2007/2008). This Hagedorn argues, is a product of 
gangs' ability to provide limited employment in informal economies in the face of the exclusions of the formal economy, and a cogent worldview in the face of uncertainty (Hagedorn 2008; Sassen 2007).

With roughly one in thirty five adults $(2.8 \%)$ in the United States under some form of correctional supervision (Glaze and Keable 2014) mass incarceration has become one of the defining facets of American social life. This rampant and racialized process has influenced gangs in several ways, the least of which being a decline in criminal activity due to the incarceration of gang members. Many gangs now operate both within and outside of prisons, with leadership and influence moving outward from prison to neighborhood. (Sheldon, Tracy and Brown 2006). Further, as has been argued by Gilmore (2007) and Wacquant (2000) prison now represents not just a site of discipline or reform, but has in fact become a means of warehousing those populations rendered economically irrelevant, uniting ghettos and prisons as spaces of exclusion (Wacquant, 2000).

Finally and most importantly for this study is the reconfiguration of urban space under new entrepreneurial regimes of capital accumulation. Despite the economic collapse of the last decade, land values in central cities throughout the United States continue to skyrocket, with many low-income residents of color displaced to expanding urban margins. In many this dynamic has resulted in the destruction of public housing and gentrification led displacement. These processes have and continue to shape the nature and behavior of gangs (Hagerdon 2006; 
Papachristos, et al. 2011; Sasken 2007), while also informing the responses from those institutions tasked with controlling gang violence.

The following section will focus on urban inequalities as they relate to gangs. I review both the ways in which gang theorists have understood the role of spatialized inequalities in the development and proliferation of gangs and how urban inequality has been understood within contemporary geographic research, emphasizing Marxist theorizing, Post-Fordist economic restructuring and the role of local planning initiatives in producing uneven and racialized urban geographies. 


\title{
Chapter II: Gangs and Geographies of Urban Inequity
}

\author{
Why Are There Gangs?
}

What is most commonly acknowledged throughout gang research is the importance of low-income and ethnic minority neighborhoods in the formation, maintenance, and proliferation of gangs (Hagedorn 1998/2008; Vigil 2002). An emphasis on poverty and residential segregation is a consistent theme throughout the history of gang studies, with each successive era of research identifying new relations between inequality and gang life, and re-framing conceptions of gangs correspondently. Evolving conceptions of the functions of urban systems and the means through which poverty proliferates have informed the ways in which gangs themselves are understood. In this way, gang studies have been closely aligned with developing theoretical understandings of cities, while gangs themselves have been shaped by these historical transformations. Although there are many potential approaches to the topic of gangs, analyzing them through a spatial lens necessarily leads to an investigation of the geographies of poverty and wealth and of the contestation of urban space. In order to better understand the role that geographies of poverty play in gang life, I will briefly summarize the ways in which poverty and neighborhood characteristics have been conceptualized within scholarly work on gangs, then discuss the macro and local-level production of poverty in contemporary U.S. cities. 


\section{Social Disorganization}

Fredric Thrasher in his seminal work The Gang: a study of 1,313 gangs in Chicago (1927) laid the foundation for much of contemporary gang research, arguing that gangs were a byproduct of disorganized immigrant neighborhoods. According to Thrasher, gangs were rooted in the combination of ordinary teenage mischief and the lack of social integration found within liminal communities that had sprung up as the result of rapid industrialization (Trasher 1927; Hagedorn 2007).

The gangs of Thrasher's time were largely white ethnic immigrant youth (Irish, Italian, and Polish) and some African Americans. These groups, Hagedorn points out (2007), were treated equally in Thrasher's theorizing, their delinquency and criminal behavior the product of their area, not their racial or ethnic identity. Thrasher understood these groups to be "interstitial", "formed spontaneously, and then integrated through conflict" (Thrasher 1927,46). The interstices that Thrasher imagined were both temporal and spatial. "The characteristic habitat of Chicago's numerous gangs is the broad twilight zone of railroads and factories, of deteriorating neighborhoods and shifting populations, which borders the city's central business district on the north, on the west, and on the south. The gangs dwell among the shadows of the slum" (Thrasher 1927, 3). He was, as a prominent member of the Chicago School of Sociology, drawing from the "ecological" model of urban development (Parks and Burgess 1922). Its metaphors of succession and invasion framed urban systems as natural environments, subject to "natural law" and 
deterministic urban processes. The "broad twilight zones" or "habitat" of gangs were then temporary, emerging rapidly and subject to transition as marginalized immigrant communities integrated into the society at large and their neighborhoods became more centralized within the systems of the city (Thrasher 1927).

Thrasher's ecological model, by emphasizing spatial processes and the role of social factors within neighborhoods, critiqued the then-dominant understanding of gangs, which attributed their formation to the criminal pathologies of immigrants. However, Thrasher's theorization (like much of the work of the Chicago School) leaves little room for the agency of individuals, much less their potential political power (Barganier III 2011). Further, the conception of poverty as the result of "natural" process shaping neighborhoods ignores the uneven power relations that are embedded within urban systems (Castells 1979).

\section{The Adaptation Model}

Building off the of Thrasher's work, contemporary gang studies have continued to focus on environmental conditions as the primary factor in the formation of gangs. This framework is referred to as the adaptation model, as it conceives of gangs as alternative social organizations, a means through which youth adapt to social and economic marginalization (Barganier III 2011). Adaptation theorists understand gangs as forming out of the failure of social institutions within impoverished communities and serving as a rational response to an environment in which 
opportunities are limited (Barganier III 2011). Susan Philips describes this protective and empowering dimension of gang life as "a net people have woven to keep themselves from falling any lower" (Philips 1999, 65).

Despite the similarities, there are several principle differences between ecological and adaptive models. First, these theorists understand urban environments not in a naturalized, ecological sense, but rather as a product of uneven power relations (Barganier III 2011). These power relations are born of a struggle between multiple groups over finite resources within cities. Gangs then must be understood as actors within a system of conflict, ones in which the powerful and powerless play coconstitutive roles in the formation of urban space (Hagedorn 2007). Here adaptation theorists are drawing heavily on Marxist political economies in their understanding of the functionality of urban systems, though not necessarily explicitly aligning themselves with Marxism as a political project.

Second, Thasher understood gangs to be interstitial, a temporary function of youthful mischief and social disorganization that would dissolve as immigrant ethnic groups assimilated. However, the persistence of contemporary gangs (including many in Portland) and the presence of older gang members challenge that notion. Adaptation scholars contend that this "institutionalization" of gangs (Barganier III 2011; Hagedorn 1991) is a response to the growth of the underground economy and deindustrialization. The collapse of the US manufacturing sector and the rise of the informal drug economy in many cities prompted gangs to become more centrally organized. This is not to suggest that gangs have become centralized as a criminal 
enterprise, but rather that gangs play an increasingly central role in the lives of gang members as other viable institutions fall by the way side (Hagedorn 2008).

In attempting to make sense of gang violence more broadly James Diego Vigil (2003) proposes a framework that he refers to as "multiple marginality", incorporating both the lived experience of gang members and macro-historical and macro-structural influences. Factors such as personal economic insecurity, fragmented institutions of social control, spatial exclusion, and psychological and emotional stress can all be linked to macro level phenomena such as racism, social and cultural repression, and displacement. More than a simple laundry list of factors influencing gang membership and violence, multiple marginality is fundamentally a model that seeks to account for the integrated and cumulative linkages between factors. This model is especially powerful in its ability to explain the ways in that reciprocal actions and reactions coheir into the lived experience that so frequently influences the individual decision to join a gang and participate in gang violence (Vigil 2010). Tracing these marginalities across space and time provides us with a way to dig into the origins of gang violence.

\section{Geographies of Urban Inequity}

As has been illustrated by the work of gang researchers, the rise of gangs in the US is fundamentally tied to the geographies of urban inequality. The character of contemporary gangs (especially "institutionalized" gangs) that have emerged since 
the 1970's is the product of important shifts in the economies, governance, and social dynamics of cities. These shifts are characterized by the transition away from manufacturing to service economies, privatization, and deregulation of markets and the devolution of state power. The dominant framework for understanding spatialized inequality in recent years has come from Marxist theorizing, which has sought to illustrate how cycles of capital accumulation and devaluation within urban systems produce spatial inequity. This framework is particularly well suited to teasing out the varied ways in which these cycles produces uneven and inequitable conditions at the neighborhood level (Goodling, Green \& McClintock 2015). Equally relevant to the understanding of urban spatial inequality is the significant body of empirical research into the recent history of urban planning and policy (Derikson 2016). In order to best illustrate the impact of these patterns, the following section will cover principle theoretical framings, major structural shifts within the global economy, and municipal governance and the intertwining of urban planning and racist ideology.

\section{Uneven Development}

The neighborhood characteristics explored by gang theorists are undoubtedly part of larger urban systems, ones in which flows of capital continually produce and reproduce uneven patterns of development across space. Uneven development, the process and condition that connects spaces of greater and lesser development, has become a central concept through which Marxist urban geographers understand patterns of urbanization. The "hallmark of capitalism" (Smith 2010, xiii), uneven 
development is tied to the logic of capitalism that seeks to remedy its own internal crisis by shifting the center of capital accumulation. This dynamic manifests at all scales, from local to national and global scales. This means that well developed areas will become decreasingly profitable until the point at which capital must shift to underdeveloped areas (Smith 2010). An interrelated concept attributed to David Harvey, "the spatial fix" argues that capitalism uses geographical expansion and restructuring as a means to address its own crisis of accumulation control and stasis (Harvey 1989): “This 'spatial fix' (as I have elsewhere called it) to the overaccumulation problem entails the production of new spaces within which capitalist production can proceed (through infrastructural investments, for example), the growth of trade and direct investments, and the exploration of labor power" (183).

Put simply, the spatial fix is a remedy to the crisis of accumulation inherent within capitalism, a remedy, it should be noted, that entails the production of new spaces. Just as the introduction of novel technologies allows for increased production and profit, the reconfiguration of existing space facilitates capital accumulation.

Central to this process is the built environment, a realm in which investors can sink surplus capital cheaply in an effort to produce further profits. Through investments in underdeveloped and/or undervalued locations, be they neighborhoods, city blocks, or larger scale geographies, "redevelopment and rehabilitation into new land uses becomes a profitable prospect, and capital begins to flow back" (Smith, 1979, p. 149). The cycle continually repeats itself, ceaselessly expanding, outward into new territories constantly, but only temporarily resolving the crisis of 
accumulation. At a macro level, this process is informed and driven by what is known as a "regime of accumulation" (Harvey 1987). These regimes are both systems of production and investment and the attendant ideologies and cultural norms that sustain them. Beginning in the early 1970's the regime of accumulation known as Fordism began to fail.

\section{The Restructuring of Urban Economics and Governance}

Fordism describes a system that allowed for the creation of large-scale profitably by linking mass production with mass consumption. It was highly efficient at producing enormous amounts of capital by providing the means though which the working class could engage in consumer capitalism. Manufacturing on a large scale could then fulfill that demand. Fordist production was also organized at a predominantly national scale, in that trade, capital supply, and economic regulation were all subject to the nation state and organized at that level (Swyngedouw 1997).

Keynesian welfarist economic policies the dominant influence on governmental decision making were closely associated with Fordism. These policies supported state control of the economy and flow of capital, fostered strong unions and led to the development of the welfare state throughout Europe and North America (Purcell 2008). ${ }^{11}$ During this period, municipal governments were generally focused

\footnotetext{
${ }^{11}$ It is worth noting that these policies were largely acted out at national levels, creating federally funded systems of support for the neediest. In the United States,
} 
more on infrastructural improvements over service provisions, a strategy that succeeded in part because social programs were supported by federal budgets. Harvey refers to this policy formation as "Urban Managerialism"(1989).

Fordism also produced urban and regional development patterns, notably the growth of suburban communities and the interstate highway system as well as the centralization of manufacturing within metropolitan centers. Suburbanization was, in fact, an important incidence of spatial fixing. The difficulty of extracting surplus capital from inner-city infrastructure which provided little means for the expansion of housing and manufacturing meant that capital that would otherwise be invested in inner cities was invested in a growing suburban housing sector. This expansion was fostered by federal housing subsidies and intended largely for white families (Goodling, Green \& McClintock 2015; Jackson,1987).

The shift away from Fordism and managerial governance began with a few major and interrelated economic events: the oil crisis of 1973, the collapse of the Brenton-Woods agreement and the subsequent severing of the dollar's tie to gold and a global property crash all contributed to a general economic downturn (Harvey 1989). The transition from Fordist to Post-Fordist production, while a gradual and uneven process, was spurred on by this crisis and defined by the changes to the means

this was manifested by Johnson's “Great Society" initiatives, which included The Food Stamp Act (1964), The Elementary and Secondary Education Act Social Security Act (1965), and The Social Security Act (1965). One result of these policies was a de-emphasis on the provision of welfare and social services at the municipal level. 
of capital generation, the re-scaling of economies and the emergence of new kinds of work. This has largely meant a transition away from manufacturing to service economies and increased flexibility and uncertainty within production and the workplace. Further, post-Fordist production began to produce new patterns of regional and global development; manufacturing migrated from northern "Rustbelt" cities to southern "Sunbelt" locations and offshore to sites in Asia and Latin America. While many inner cities had already started to lose manufacturing employment to the surrounding suburbs, the reorganization of post-Fordist production would only compound those problems. Inner-city industrial cores and the working class neighborhoods that bordered them would rapidly deteriorate, forcing municipalities to rework their strategies (Anderson and Wilson 2014).

The collapse of Fordism ushered in a new era of governance influenced by the economic philosophy known as neoliberalism. Based around the principles of privatization, deregulation of markets, and the devolution of power to local authorities, neoliberalism would under the Thatcher and Reagan regimes, become increasingly powerful as an organizing principle of national and global economies (Harvey 2005). This reorganization of production would increase the degree of competition amongst cities seeking to attract capital, necessitating a new form of urban governance, "entrepreneurialism", with its "diminished role of the city government as the provider of welfare services and collective consumption" (Hall and Barret 2012). Entrepreneurialism largely seeks to attract capital investment in order to expand municipal tax bases through investment in the kind of housing and 
infrastructure associated with the work and play of the new "creative class" (Derikson 2016). This is often accompanied by "public-private" partnerships in infrastructure along with subsidies and tax breaks (Smith 2002).

The decline of inner city manufacturing and the attraction of downtown areas to post-Fordist creative economies have produced a growing professional class within once-devalued urban areas. This has resulted almost universally in gentrification and its related displacement of low-income communities in a wide range of cities across Europe and North America. Neil Smith has employed uneven development as a framework to elegantly illustrate the process of gentrification more generally, detailing the process through which undervalued neighborhoods are deemed blighted by city authorities and therefore primed for redevelopment, almost always resulting in some form of displacement of the former residents (Smith 1979). The means through which municipal governments achieve this goal (including the policing and privatization of public space to the detriment of the poor, homeless, and, often people of color) Smith describes a "revanchist", meaning a vengeful retaking of the city by capital from the frequently socially marginalized residents. Smith's "revanchist city" illustrates keenly the social dimensions of uneven development, its profound influence on the lived experience of both the most and least privileged within our society (Smith 1996). 


\section{Planning Histories}

Local planning actions are also important to consider in the creation of racialized and segregated spaces within American cities (Derikson 2016). These policy practices are closely related to the regimes of accumulation I have previously detailed, though the particular forms are and were highly localized. The role of these planning initiatives has traditionally been to support the established means of capital accumulation and therefor, has frequently meant the further exclusion of already marginalized groups. Many urban scholars have contributed important work addressing how housing policy (Gotez 2013; Vale 2013), infrastructure development (Jackson 1987), and urban planning (Davis 1991) have all contributed to the uneven distribution of wealth and opportunity along racial lines. Work by Sugrue (1996) and Jackson (1987) emphasizes the role of policy over residential preference in the creation of de facto segregation, showing that the creation of neighborhood segregation is, in fact, the "result of the actions of the federal and local governments, real estate agents, individual home buyers and sellers, and community organizations" (Sugrue 1996,11). The actions of local actors have taken the form of practices such as redlining, restrictive covenants, block busting and urban renewal policies of "slum clearance" (Pietila 2010; Gibson 2007a; Avila and Rose 2009) the destructive impact of all of which is difficult to overstate.

This is by no means an exhaustive review of the means through which local planning initiatives have worked to further marginalize low-income populations of color. However, in considering these policies broadly, it is worth noting what has 
been gained by instituting such exclusionary policies. Derickson argues that "the Fordist virtuous circle of economic growth, urban development and creation of the (white) middle class depended upon and reified racialized exclusion" (Derickson $2016,3)$ That is to say, that marginalization of people of color is not purely a byproduct of uneven economic development, but an integral component. Similarly, Brahinsky suggests that we seek out "the embeddedness of political economies with racial constructs.” (Brahinsky 2014, 1272). Questioning the policing of racialized bodies must take these dynamics into consideration and ask what role this policing takes in maintaining established means of capital accumulation.

In this chapter I have sought to illustrate the close connections between the formation, proliferation and maintenance of gangs and the inequalities inherent to urban capitalist economies. These inequalities can be attributed to both the local and macro level dynamics, be they of the industrial city of Thrashers (1927) time or of the contemporary, globalizing cities discussed by Hagerdon (2007) Sassen (2007) and Vigil (2010). Post-Fodist economic restructuring has further entrenched many inequalities relating to housing, employment social and spatial exclusion, creating the conditions for the further growth of gangs. Just as the urban form itself has been shaped by this transition, the means through which cities are governed has also changed. Neoliberal reforms have deeply impacted two institutions central to my study: policing and social service provision. In Chapter Three, I examine these changes and how they relate to the prevention of youth and gang violence. 


\section{Chapter III: Policing and Social Service Provisions}

Since the early days of the problem, responses to gang violence in Multnomah County have been characterized by a holistic approach, integrating the efforts of law enforcement and service providers, municipal governments and private sector nonprofits. This integrative strategy is not unique to Portland and has increasingly become the dominate form in gang violence prevention. Spergel and Curry (1991) in their study of gang responses in 45 cities, grouped strategies into four broad categories: community organization (referring to the enhancement of relationships between differing groups addressing gang issues within a city), social intervention (usually manifest as youth outreach or street level counseling), opportunities provision (the attempt to provide, jobs training and education), and suppression (a variety of law-enforcement strategies, including those of police, prosecutors, and legislators). Spergel and Curry found that within "chronic gang problem cities" the most effective methods were those categorized as opportunities provision, with community organization ranked second, and suppression and social intervention ranked third and fourth respectively. However, as Shelden, Tracy and Brown (2013) point out, "various components of each of these major strategies should be used in combination. This is because it is erroneous to assume from the data, presented by Spergel and Curry that an entire category of various strategies will not work" (Sheldon, Tracy and Brown 2013: 288) This approach of combining strategies and integrating the agencies most well equipped to implement each particular strategy has 
become increasing popular among municipalities and widely supported at state and federal levels (McGarrell et al. 2103).

Understanding the spatialities of comprehensive and multifaceted approaches to the control of gang violence requires an understanding of their component parts, namely law enforcement and service provisions as well the specific means through which these differing institutions are integrated. This chapter will provide an overview of recent work in geography and related fields regarding the functions and practices of the police and social services. Both of these realms have been dramatically altered by neoliberal restructuring. As neoliberalism became more central as an organizing concept during the 1980's, concerted efforts were made by the Reagan, Bush and Thatcher administrations to "roll back" the state, decimating social services and acting to significantly change the function and practices of the police (Harvey 2005; Wolch 1989; Yarwood 2007). Equally important is the rise of a form of local governance that has required the integration of governmental and nongovernmental institutions in the planning and provision of services. Governance in the broadest sense refers to the policy and decision making relationship between governmental and non-governmental organizations (Elwood 2002). While this dynamic has existed within urban systems historically, the combined approach has expanded and become more entrenched under neoliberalism. As Sarah Ellwood states,

"What is evident is that the rapid proliferation of programs and policy changes intended to expand citizen involvement and to reassign certain responsibilities for neighborhood revitalization and service delivery to community based organizations 
are part of a fundamental shift in the process through which local-level urban change is planned, negotiated and implemented" (Elwwod, 2002, 755).

Neoliberal restructuring (and specifically the emphasis on collaborative governance) then represents a means through which policing and social services are theoretically and practically integrated.

\section{Geographies of Policing}

Fyfe (1991) wrote in regards to policing that "interest in the topic remains on the margins of human geography's research agenda" (Fyfe 1991,247). While there have been some notable exceptions (Herbert 1997), 25 years later this statement remains generally true. The spatial analysis of crime incidents via Geographic Information Systems (Monmonier 2006; Curtis and Mills 2011), impacts of fear of crime on spatial perception and behavior (Valentine 1989), and geographies of law (Blomley and Rowbotham 1996) have all been emphasized within the discipline, while the spatial practice of policing has not (Herbert 1997; Yarwood 2007). However, Yarwood suggests that a better understanding of the police, both theoretically and empirically, offers the potential to inform our understanding of the changing functions of the state. As the means through which state power exerts its control over space, geographies of police action then reflect the political geographies of a given state and dictate in part the relationship between the public and the state (Fyfe 1991; Yarwood 2007). 
This relationship between the state, space and the police is the subject of Steve Herbert's text Policing Space: territoriality and the Los Angeles Police Department (1997). He examines the uses and perceptions of space by police in Los Angeles via a series of ethnographic vignettes based on his' experience conducting "ride-alongs" with officers. Herbert draws on theories of territoriality to explore the spatial relations of police, identifying six normative orders which function as rules and practices for policing that produce these spatial relations; the law, bureaucratic regulation, adventures/machismo, safety, competence and morality. Herbert argues that police perceive and shape space through the lens of these orders. Although race is not a central variable in Herbert's analysis, he does argue that police officers may see ethnic minority neighborhoods as unsafe and somehow immoral, values which then dictate the spatial practices of officers. Of particular importance is the way in which these normative values are tied both to the centrality of the state and the discretion of individual police officers. Herbert illustrates the complex way in which police power is subject to the direct control of the state, while recognizing the influence of individual actors in how that power is implemented spatially (Herbert 1997).

Richard Yarwood argues that policing, like many other state functions, has been subject to neoliberal restructuring. He breaks these down into three distinct manifestations; a growing array of institutions conducting the work of policing, the importance of performance data, and the almost universal adoption of communitybased approaches (Yarwood 2007). 
The creation of a broader array of organizations conducting the work of "policing" (what Yarwood calls an "extended policing family") reflects the neoliberal ethos of a devolved state (Yarwood 2007). As private spaces in the form of enclosed shopping malls and gated communities have become more prominent in urban landscapes, so have private police forces. Voluntary policing, most notably in the form of Neighborhood Watch, serves a similar function while conforming to the neoliberal discourse of "responsibility" emphasizing the individual and local institutions over the wider social structure (Yarwood 2007). Both of these approaches act to preempt potential crimes, a focus that exacerbates spatial inequalities by acting to exclude undesirable people and activities from spaces under their control (Yarwood and Paasche 2015). An important implication of this change is the spatial exclusion of populations deemed undesirable. These exclusionary practices have been the subject of geographic work more broadly, in ways that perhaps emphasize a more centralized role of municipal governments and their ability to institute ordnances, over the role of police (Herbert and Brown 2006; Mitchell 1997).

A second impact of neoliberalism on policing is the increased use of performance data (Yarwood 2007). The use of this data is based on market principles that seek to maximize the cost-efficiency of public institutions. Police forces are being reorganized spatially to achieve the goals derived from data collection, with policing areas being determined through the use of GIS-based 'hot spots' to determine the areas of maximum resource need. Herbert (1997) shows that some officers manipulate the ways in which they report calls in order to improve performance 
figures. This kind of de facto practice has been shown to have racially and spatially uneven implications.

A case in point: Lynch et al. (2013) present an investigation of the practice of selective drug law enforcement in San Francisco. The authors look at how selective drug law enforcement along racial lines is geographically oriented; constructing social identities based on perceived disorder for certain neighborhoods. Lynch et al. suggest that enforcement patterns in cities characterized by their high real-estate values and 'playground' consumer economies may be more prone to punitive drug enforcement along racial lines, despite their liberal character. This policing, according to the authors, would most likely be concentrated in contested neighborhoods experiencing transitions associated with gentrification.

Finally, what is known as community-based policing has become extremely popular in jurisdictions throughout the world. This practice generally is understood as a proactive effort to work with, rather than against communities in the planning of police operations. This may mean increased foot patrols, the opening of substations, police attendance at community meetings and gatherings, and the integration of police with social service initiatives. Community policing is frequently framed as an effort to return to a more integrated and inclusive form of police and citizen relations. However, Herbert (2005) argues that community policing as a model should be abandoned; "Its promise remains unrealized, largely because it was never realizable" (Herbert 2005). The crux of Herbert's argument centers on the concept of "community" which he argues holds different meanings for police and residents and 
therefore the relationship between police and community exists in varied and contested ways. In this sense the concept of community, being ontologically "lite", cannot bare the institutional "weight" of community policing. Further, Herbert notes a key element of police culture is a sense of "separateness", which is totally incongruent with collaborative practices central to the concept of community policing. Community, for Herbert, can perform two functions within neoliberal governance: "it can stand as a recipient for devolved authority, and it can legitimate that very devolution" (Herbert 2005, 852). Community policing then, especially for communities that have historically been subject to police repression, entails not only picking up the slack of a diminished state authority, but also legitimating authority, regardless of its potential misuse.

It should be noted that while geographers have tended to focus on the impact of policing on socio-spatial configurations, criminologists have worked to better understand the impact of space and place on the practices of policing. Crawford (2010) offers important insights into how space shapes the everyday practice of policing including those associated with philosophies of "defensible space" and the "broken windows" theory.

Geographies of policing, while remaining undeveloped, offer a means to understand how a state power control and produces space. Yarwood suggests that perhaps the reason that geographers have avoided this line of inquiry is the relative difficulty of theorizing policing, given the impact of both de facto local actions by police departments and individual officers, and de jur state policy. In other words, 
geographers need to take into account the complex relationship between the macrolevel shifts in political economies and the restructuring of criminal justice, and the very local impacts of these shifts (Yarwood 2015). To this point, Brenner and Theodore's (2002) conception of "actually existing neoliberalism" meant to emphasize the ways in which neoliberal restructuring is defined by local institutional and political contexts, is helpful in understanding the unevenness of policing across space.

\section{Social Service Provisions, "The Shadow State” and Local Governance}

As with policing, the provision of welfare has been subject to neoliberal restructuring. This was first closely investigated by Jennifer Wolch (1989) through her metaphor of the "shadow state". As neoliberalism became more central as an organizing concept during the 1980's, concerted efforts were made by the Reagan, Bush and Thatcher administrations to "roll back" the state, decimating social services. The "shadow state" as detailed by Wolch describes the rise of a contemporary volunteer and nonprofit sector that is involved in the delivery of social services previously provided by wholly public agencies (Wolch 1989). It is not only that the state has retreated from providing these services, but it has also expanded its oversight and control of service providers by sub-contracting services and using the coercive power of grant funding and tax remittances. Those organizations whose practices or ideologies do not fit within the parameters set forth by the state will therefore not be permitted (Wolch 
1989). This transference is not uniform, however, and the variations in the degree to which non-profits and volunteer organizations are involved in service provision depend on local context. Wolch and Dear (1993) also provided important empirical work on the way that welfare restructuring produced specific urban spatialities. Their study on homeless-service provisions in Los Angeles illustrated that homeless individuals gravitated to sections of the city where they could find the services they depended on. As more individuals migrated to these service-filled sections of inner cities, an increasing number of services would locate to that area. They termed this phenomenon the "service dependent ghetto" (Wolch and Dear 1993).

As I have mentioned before, the role back of the state meant not only an increased responsibility for service provisions placed on non-governmental institutions, but also an increased role in the decision and policy making process. Sarah Elwood (2004) compares practices and discourses of collaborative approaches to urban governance in the United States and United Kingdom. She finds that language and principle concepts associated with these initiatives are similar, but that the state structure in these two countries determines the local outcomes. She illustrates that while U.S. initiatives may put greater power in the hands of civil society groups to plan, they suffer from diminished resources to enact these changes. Inversely, local actors in the U.K. may have access to greater technical and financial resources, but have less control over agendas, goals, and strategies. Both of these outcomes represent challenges to citizen participation and democracy more broadly. 
The integration of service provision and policing as a response to gang violence not only reflects what is considered best practices (Sheldon, Tracy and Brown 2013) but also changing philosophies and practices of policing (Yarwood 2007; Herbert 2006), the transformation of welfare provisions (Wolch 1989), and the valorization of collaborative governance (Elwood 2004; Purcell 2009). The precise means and strategies through which an integrated approach to gang control has been implemented in Multnomah County is the subject of this study. The following chapter, in addition to detailing the pertinent geographies of inequality, sheds some light on how gang control methods emerged in Multnomah County during the 1980's and 1990's. 


\title{
Chapter IV: Geographies of Poverty and Race, and the Emergence of Gangs in Multnomah County
}

\author{
Multnomah County's Gang Geographies as Geographies of Poverty and Race
}

The following section focuses on localized geographies of poverty, and how these geographies have produced conditions conducive to a thriving gang life in Portland. Gangs in Portland have historically been made up predominantly of African American youth and as such responses to gang violence have historically been centered in predominantly Black neighborhoods. To this point, it is necessary to trace the threads of both economic inequalities along with residential segregation. As I mentioned in the second chapter, these are not separate phenomena, rather they are co-constitutive. The three specific areas I reference in this section have interrelated histories of residential segregation, income inequality, gentrification and displacement. Put in Vigil's (2010) terms, we can understand these areas as having been subject to "multiple marginalities". We can also understand these areas as shaped by economic restructuring and the more general dynamics of uneven development. What follows is a brief account of the unique geographies of gang violence in Multnomah County and the emergence of that violence.

\section{Albina}

The Albina district of North and North East Portland has for the past century been associated with the city's relatively small African American population. During the 
$20^{\text {th }}$ century, "the simultaneous processes of racial residential segregation and disinvestment" (Gibson 2006, 4) would transform Albina into a distinctly racialized and undervalued space within Portland. Beginning in the teens, Portland's small Black population, which had been centered around the Far West Hotel in downtown, was gradually forced through the use of restrictive housing covenants into the Southern portion of the Elliot neighborhood (McElderry 2001). These housing restrictions took the form of local statutes and the actions of private lenders and landlords (Gibson 2007a). The 1940's and the advent of the Second World War, saw the mass migration of Blacks from the rural South to West Coast cities. Portland, like Los Angeles, Oakland and Seattle became an epicenter for war time ship building. The war years would see Portland's Black population grow from roughly 2,000 to 23,000 (McElderry 2001). Most of these new residents would be restricted to the recently constructed workers housing in Vanport and Guild's Lake in North Portland and the Elliot and Bosie neighborhoods in North East (Gibson 2007b). In 1948, the Columbia River flooded destroying Vanport and leaving more than 18,000 residents homeless. After the flooding of Vanport and the Housing Authority of Portland's refusal to construct new public housing (McElderry 2001) Blacks continued to be funneled into the Albina area, while white residents would leave en mass for suburban communities to the west and the east of the city (Gibson 2007a).

Over the next several decades, Albina would become both the heart of Black Portland and suffer from ongoing structural devaluation. By 1960, four of five Black Portlanders lived within the Albina area, with a gradual movement of residents farther 
north (McElderry 2001). The neglect of housing stock by absentee landlords and the lack of capital investment in the area would lead to a growing perception of the neighborhood as blighted. Throughout the 1960's and 1970's several large scale urban renewal projects, funded both federally (Emanual Hospital) and municipally (Memorial Coliseum) would lead to the destruction of a significant portion of Albina's housing stock, which along with the flooding of Vanport, would become part of a narrative of the displacement and community disruption amongst Portland's Black residents (Gibson 2007a).

This narrative would culminate in the mass displacement of African Americans via gentrification beginning in the 1990's. Throughout the 1980's, official neglect of the area led to a sharp decline in the value of homes in Albina, so much so that nine neighborhoods within the area received special reassessments of property. As of 1989, only 44 percent of homes in Albina were owner occupied (Gibson 2007b). In part these trends were due to the lack of conventional mortgages available to residents and the rise of predatory lending practices, making it difficult for Black residents obtain and then retain homes. Compounding these problems, the crack epidemic that devastated inner city communities throughout the country hit Portland as well, causing significant social disruption. By the 1990's the white population of Albina had begun to steadily grow. The lower Albina neighborhoods of Irvington, King-Sabin, Humboldt, and Boise, which had seen a significant decrease in their African American populations in the 1980's gained white residents in greater than average numbers (Gibson 2007a). 
Major public redevelopment projects also played a role in the growing desirability of Albina. The Portland City Councils Albina Community Plan, adopted in 1991, funded beautification projects and the development of vacant lots. The Interstate Corridor Urban Renewal Area, Portland's largest urban renewal area, provided large amounts of funding for development projects, notably the light rail expansion that opened along Interstate Avenue in 2004. This direct transit route to downtown, along with the preponderance of affordable housing stock in the area would draw many newcomers to Albina (Goodling, Green and McClintock 2015). Ultimately this would lead to a near total demographic reversal in many of the census tracts that make up the Albina district. From 2000 to 2010, 38 census tracts within Portland became whiter, with an out migration of nearly 10,000 people of color, mostly African Americans (Hannah-Jones 2011).

\section{The Columbia Villa Projects}

As the wartime production in Portland's shipyards ramped up, the lack of adequate housing for defense workers became an increasingly pressing issue for Portland. The seriousness of the issue led to the development of the Housing Authority of Portland (HAP) under the United States Housing Act of 1937 (HAP is now known as Homeforward). HAP's centerpiece and Oregon's largest public housing project, Columbia Villa, was built in the early 1940's. Situated adjacent to the Kaiser Shipyards in North Portland, the development was initially intended as permanent housing for defense workers. A low density, suburban style development with 
curvilinear, tree lined streets, it was designed to appeal to working and middle class families. Throughout the 1950's and 60's long lists of perspective tenants and low vacancy rates were the norm for what was then considered a desirable community (Gibson 2007b; Blake, Abbot and Lindberg 1990). Unlike many other large public housing projects, at no point did Columbia Villa suffer from the kind of hyper segregation frequently associated with developments of that type. It was in fact, significantly more diverse than the city of Portland itself (Gibson 2007b). Originally largely populated by non-Hispanic Whites, by the 1980's a third of the residents were African American, along with Southeast Asian immigrant groups, Hispanics and American Indians (Blake, Abbot and Lindberg 1990).

However, as the facilities began to age, Columbia Villa acquired some of the stigma commonly associated with public housing (Gibson 2007b). Beginning in the mid-1980's Columbia Villa became the site of increasing violence, drug dealing, and gang activity. In the early 1990's the United States Department of Housing and Urban Development instituted the Housing Opportunities for People Everywhere (HOPE VI) program. The program was designed to fund the demolition of public housing projects deemed "severely distressed". In 2003, HAP began sending eviction notices to residents of Columbia Villa, and in 2005 a new, more compactly designed site with a greater number of units, New Columbia, would open to its first tenants. Unfortunately, only roughly $30 \%$ of the original tenants would return, and many former residents would settle in the eastern portion of Multnomah County. As Gibson notes, many Black residents who relocated found their new neighborhoods to provide 
less of a sense of community than the rare space of Columbia Villa where their minority identity was less pronounced (Gibson 2007b).

\section{East Portland and Gresham}

Throughout the North America, a new spatial manifestation of poverty has emerged. As the rate of poverty within central cities began to decline in the 1990's, the rate within suburban communities edged upward. By $2000,49 \%$ of people living in poverty resided in a suburban community, up from $46 \%$ ten years earlier (Berube and Frey 2002). This re-concentration of poverty has continued throughout the past decade, influenced in part by the "Great Recession" and its lingering impacts (Cooke and Denton 2014). Portland, despite its progressive planning initiatives has not managed to avoid this trend. The number of people living in poverty in Portland's suburbs increased almost 100 percent between 2000 and 2011 (Goodling, Green and McClintock 2015). Within city limits, poverty increased by more than 71 percent, much of it settling in East Portland (Kneebone and Williams 2013).

During the post-war period when Portland's Albina district was subject to devaluation and segregation, the suburbs experienced tremendous growth in new residential construction. White Portlanders moved outward from the city center with the aid of federally subsided housing loans and newly constructed freeways. Neighborhoods on each side of $82^{\text {nd }}$ Ave (an important east-west dividing line in the social geography of Portland) gained 30,000 residents between 1945 and 1960 
(Goodling, Green and McClintock 2015). This new construction would by the 1970's begin to overwhelm infrastructural capacity, specifically an inadequate septic system that would become the basis for Portland's annexation of unincorporated land in East Multnomah County. This annexation in fact represented an important source of income in the form of tax revenue for Portland, given the diminishing property values of inner city neighborhoods (Goodling, Green and McClintock 2015). Ultimately however, the flow of capital would reverse itself and as property values in the inner North and North East increased, leading to a steady displacement of low-income residents, especially African Americans (Gibson 2007a).

The Rockwood neighborhood on the Portland/Gresham border is perhaps most emblematic of the shift of activity from inner city neighborhoods to the East County. Rockwood is a largely low income community nestled between the eastern border of Portland and the more affluent areas of the city of Gresham. It has a significantly higher proportion of minority residents than Portland or neighboring areas of Gresham, including immigrant and refugee populations, along with newer, established but displaced African Americans (Hagerty 2014). Gresham annexed Rockwood in 1980 when sewage issues forced the cities of Gresham and Portland to incorporate those parts of Multnomah County that were previously unincorporated (Moore 2010). Light rail, which was extended to Rockwood in 1986, was touted as a boon to the suburbs economics and livability. However, this may have hastened gentrification within inner city of Portland, as it has provided a means for working poor without access to vehicles to live outside the city proper. Rockwood has also 
become the site of an explosion of subsided housing, in part due to the failure of Home Forward, Multnomah County's Housing authority, to equitably distribute units throughout the county in its Section 8 program and the rentals it directly controls (Schmidt 2012). This has in effect produced a kind of warehousing of the county's most vulnerable families and individuals, those who would most benefit from the amenities opportunities available in inner city neighborhoods (Goodling, Green and McClintock 2015). The ongoing impacts of this redistribution on Multnomah County's low income communities remains to be seen, but already patterns relating to the accessibility of resources and amenities suggest that some of the inequities associated with urban poverty are compounded in a suburban context (McKenzie 2013). Given these circumstances, it should come as no surprise that gangs have become increasingly entrenched in East Multnomah County. Police, service providers, and outreach workers are increasingly focusing on this area of the county. The specific geography of gang life has also changed in character with the drift eastward. There is a diminished focus amongst these gangs on the preservation and expansion of territory. Instead of holding streets or city blocks, emphasis is being placed on apartment complexes dominated by particular gang sets (VanderHart 2014), perhaps a reflection of the changing nature of the areas built environment. 
The most common narrative suggests that enterprising gang members from Los Angeles had in the mid-1980's begun dealing crack cocaine in Portland and establishing turfs in North and North East Portland. Law enforcement in Portland was up until that point less organized and unaccustomed to combating drug dealing, making it a more comfortable environment for drug dealers. As gangs from California gained a foothold, the drug economy in Portland reorganized from several small individual operations into larger centralized operations with connections to larger supply chains. Young people in Portland were soon recruited act as low level drug dealers, with "guys from Los Angeles that were having these parties, called 'recruiting' parties and 'Crip' parties” (J. Brown 1995, quoted in Lindberg, 1996, p.62). The number of drug houses increased dramatically, with several hundred by the mid 1980's, along with highly stylized gang graffiti that had previously been unknown in Portland (Lindberg 1996). This narrative seems to suggest that gangs in Portland were the product of intervention by outside forces. While it seems likely that there were individuals from out of state who may have been influential in the process, most gang research suggests that the "invasion" of a community by gangs is less likely than the migration of individual gang members who are looking for an improved quality of life or simply the cultural transference gang life through exposure to media portrayals (Sheldon, Tracy and Brown 2013).

While there was recognition of a growing gang presence among patrol officers and service providers, city officials actively ignored the emerging crisis. Violent incidents involving youth in North East Portland were minimized, with the suggestion 
from police and city officials that these were merely isolated incidents and not part of a wider pattern. Lindberg (1996) suggests that this official reticence to acknowledge growing gang activity was connected to three major points: city officials desire to preserve Portland's image as a "livable" city, construction of high visibility projects intend to draw business to North East Portland (the Oregon Convention Center and the remodeling of the Lloyd Center Mall), and a concern that a concerted effort at suppressive policing of young Black men would be politically unfavorable. This final point alludes to the Portland Police Bureau's troubled relationship with the African American community, which at the time had been recently exacerbated by multiple scandals. These included officers dumping the bodies of possums on the door step of a Black owned restaurant and the death by chocking of Lloyd D. Stevenson by Portland Police Bureau (PPB) officers (SerbuLo and Gibson 2013) in an incident eerily similar to the recent killing of Eric Garner.

However, efforts were being made within local government and community organizations to address what many saw as an emerging problem. Multnomah County's Juvenile Justice Department established a program known as the Gang Resource Intervention Team (GRIT) which was instrumental in setting the tone for future responses by integrating individual and family services for gang-involved youth under probation. The Portland Police Bureau established their own Gang Enforcement Team (GET) in an effort to identify and intervene individually with gang members. The North and North East Neighborhood Coalitions (quasi- 
governmental citizens groups) established their own gang outreach program (Lindberg 1996).

In August of 1988 Joseph "Ray Ray” Winston, a well-liked and popular eighteen year old, was shot and killed in in a drive-by shooting on the grounds of the Columbia Villa housing project. Winston's death is widely considered Portland's first gang homicide. Winston was, or at least claimed to be, a Columbia Villa Crip. His assailants, according to trial testimony, were Westside Piru (a Blood set) who were attempting to intimidate the Crips and had no intention of killing anyone. This event forced the attention of city officials and the larger Portland community and set in motion many of the early policy initiatives aimed at addressing gang violence (Lindberg 1996).

Then Governor Neil Goldschmidt organized the Youth Gang Strike Force (YGSF), a multiagency law enforcement group focused on prosecution, suppression, and intelligence gathering. The YGSF focused its attention on the arrest and prosecution of high level drug dealers, which it was successful in doing, but soon found that gang violence persisted regardless. In response to the death of Ray Ray Winston, a push was made by the city of Portland, HAP and local non-profits at a localized intervention, The Columbia Villa Service Project. The concept was to locate a small, community-oriented police force, along with comprehensive and integrative service provisions within Columbia Villa (Lindber 1996; Gibson 2007b; Blake Abbot and Lindberg 1990). Particularly successful was the deployment of a small group of bicycle cops who were assigned strictly to Columbia Villa and operated under the 
then novel community policing philosophy. This tactic was in many ways successful in that it lowered levels of violence with Columbia Villa, though it tended to displace the problem to neighboring areas. Gangs and gang violence remain part of the social fabric of the area (Duin 2012).

Lindberg (1996), characterizes these early interventions as approaching gangs as a problem defined by a social causation, "one which would not disappear just because a few gangsters were arrested, and one which would require long term prevention and intervention methods"(Lindberg 1996,106). This involved the integration of multiple different agencies specifically focused on outreach and service provision, along with those focused on enforcement and prosecution, an approach has been consistent in gang control efforts in Multnomah since the late 1980's (Lindberg 1996).

Similarly law enforcement in the form of PPB and JJD early on sought less punitive approaches to the problem and deployed a community policing model, working specifically to integrate themselves into the communities most impacted. At the time this took the form of outreach to

As the 1990's progressed, Black gangs became more entrenched within North and North East neighborhoods. Gangs during this era were particularly visible, claiming and defending turf and "flying colors". The former head of the Gang Enforcement Team, Dave Hendrie describes the intensity of this era,

"When I became a police officer, the gang world was very easy to spot... Gang members wore uniforms, they wore colors... You'd hit a street corner at $9^{\text {th }}$ and Alberta and there would be 15 guys dressed all in red and fully accented out. Those 
were your guys, hardcore gangsters, your Loc'ed out Pirus, your Woodlawn Parks, 9 Block guys...then you would cross over MLK...you'd hit Peninsula Park and there would be 15, 20 guys, Rollin' 60s all dressed down in their colors." (Dave Hendrie, personal communication, March 19, 2016)

This quote references a historical geography of gang affiliation within Portland;

Martin Luther King Boulevard (formally Union Boulevard) represented an East/West dividing line between Bloods and Crips. Violence then, was sometimes associated with territorial transgressions. While Latino and Asian gangs were also active during this period, violent crimes were largely associated with Black gangs, meaning gang enforcement was centered with the Albina area. This took both the form of patrolling and the Gang Enforcement Team being officially assigned to the newly created North East Precinct ${ }^{12}$.Gang enforcement during this period was also closely related to efforts at controlling crack cocaine sales, which at the time was an issue of particular importance in the Albina area. ${ }^{13}$

Violence peaked in Portland in 1995, a year with 8,857 reported violent crimes. However, 1996 saw a decrease of nearly 1,000 violent crimes in concurrence with cities around the country. By 2000 violent crime in Portland had dropped to

12 "If you think about how small that footprint is, think of two hundred plus shootings (shots fired calls, things like that) a year in a very confined space. It was very, very, busy and very, very concentrated." (Dave Hendrie, personal communication, March 21, 2016)

13 "Open air crack deals was pretty much hand in hand to deal with gangsters and drugs. It was a rare gangster that you arrested ... Let's say you arrested a gangster that had a gun, or for a warrant or something like that...that didn't have either evidence of drug dealing which was back then... Big wads of cash, rolls of twenties, pager, they even had cell phones when I started right. Residual narcotics on their person little crumbs of crack that were in their back pockets or things like that." (Dave Hendrie, personal communication, March 21, 2016) 
5,706 with a 60\% decrease in murders (Portland Police Bureau 2016). This in many ways reflects a national trend of decreasing gang associated violence decreasing through-out the late 1990's and into the early 2000's (National Gang Center 2015). Several respondents to this study attribute this decrease to the use of mandatory minimum prison sentences, which in Oregon were instituted under Ballot Measure in 1994. This meant that certain violent crimes against person would receive a sentences of 10-15 years with no possibility for any reduction in sentence, such as for good behavior (Oregon Department of Corrections 2016).

While violence in the early 2000's dipped significantly (leading PPB to disband a gang enforcement specific patrol unit) (Vanderheart 2014) a gradual uptick of violence beginning in 2008 would reengage many of the agencies and organizations aimed at preventing gang violence. These efforts would necessarily have to adapt to a new geography of gang violence, one that was becoming increasingly, but not strictly, focused on the suburbs of East Multnomah County. 


\section{Chapter V: Findings}

In considering the strategies for the prevention and reduction of gang violence, several themes emerge from my analysis. The first being the emphasis on coordination and collaboration between law enforcement and social service providers at the city and county level. Non-profits and community members are also increasingly integrated into these efforts. This approach offers multiple benefits to the efficacy of violence prevention. However, this is a complex system in which organizations have varying degrees of power and authority. The second is the ongoing movement of services and infrastructure associated with public safety to neighborhoods in East Multnomah County. This is a broader trend and not specifically related to youth and gang violence, however, many initiatives linked to youth and gang violence prevention and enforcement are taking on neighborhoodspecific framings. This relocation necessitates the production of new forms of spatial knowledge, specifically mapping initiatives that seek to guide the location of these services.

Finally, I cover the perceptions of the impact of gentrification on the issue of youth and gang violence. By and large, respondents identified gentrification and the subsequent displacement of low-income communities of color as profoundly impactful on issues of youth and gang violence. This impact takes multiple forms: adverse effects on community cohesion, challenges to traditional gang territoriality and an increased difficulty in addressing the problem, be it through social services efforts or law enforcement. 
The overall structure of youth and gang violence prevention in Multnomah County can be understood as being composed of three separate and integrated functions of governance: county and municipal administration, law enforcement, and non-profit social service providers. Each of these different functions is comprised of individual bodies that work in varying degrees of collaboration and with differing abilities to exert power over the processes of youth and gang violence control. What follows is a brief cataloging of these institutions and their role within the youth and gang violence prevention structure.

\section{County and Municipal Government Institutions}

Youth and Gang violence prevention is addressed by several administrative institutions within local governments in Multnomah County. These institutions exist at both the municipal and county levels with a primary task of administering and procuring funding and developing and implementing policy.

The two municipalities in Multnomah County most directly affected by issues of youth and gang violence, Portland and Gresham each operate an office directly tasked with addressing the issue. In Portland, this is the Office of Youth Violence Prevention (OYVP), which responds directly to the Mayor of Portland. Amongst the OYVP's key initiatives is the managing of funding for the Gang Impacted Families Team (GIFT) and the Street Level Gang Outreach Workers (SLGOW). Gresham, 
operates a similar office, albeit a smaller one, in the form of a single Gang Prevention Policy Advisor, with a focus on assessing the city's gang problems, coordinating approaches with partner organizations and providing funding to for anti-violence initiatives (Office of Youth Violence Prevention 2016; City of Gresham 2016).

At the county level, multiple agencies are involved at some level with youth violence prevention. These include the Multnomah County Department of Health, with its Striving to Reduce Youth Violence Everywhere (STRYVE) initiative, and the Department of Community Justice Juvenile Services Division which recently hired a Gang Violence Prevention Specialist. Multnomah County's Local Public Safety Coordinating Council (LPSSC) is perhaps the most directly involved in issues of youth and gang violence. Coordinating councils like LPSSC are collaborative partnerships which exist to address complex social issues within local governance, and became a prominent feature of the American civic landscape beginning in the 1990's (Allen 2005).

Beginning in 2011 LPPSC instituted the "Action Plan to Reduce Youth and Gang Violence" along with a Youth and Gang Violence Subcommittee tasked with developing and implementing a comprehensive violence reduction model. This approach was based in part from Multnomah County's Participation in Attorney General Janet Reno's Strategic Approaches to Community Safety Initiative (SACSI, locally know, as STACS) beginning in 1998 (Local Public Safety Coordinating Council 2016). As one of five sites for this Federal initiative, Multnomah County 
developed a model based off of strategies supported by the Federal Office of Juvenile Justice and Delinquency Prevention (OJJDP).

A stated goal of LPPSC's Action Plan to Reduce Youth and Gang Violence initiative was "Greater coordination of operations, programs and services among participating justice agencies, community organizations and local governments in Multnomah County and, in particular, between operations in West and East County"(Local Public Safety Coordinating Council 2016).

These institutions are directly involved with the creation of policy, procurement of funding and the coordination of multiple service providers.

\section{Social Service Providers}

The Multnomah County Comprehensive Gang Assessment, commissioned by LPSSC, identified a total of 260 programs, administered by individual nonprofits or governmental organizations, which cater to youth and their families. Of these 260, only five percent (twenty-two programs) specifically focus on serving gang members (Local Public Safety Coordinating Council 2014). Amongst this subset of programs focused on gang issues, the assessment identifies two categories of programs: gang specific programs, in which gang violence is a primary concern, and gang responsive programs, in which gang violence is not a primary concern, but have institution 
experience or knowledge relating to gang issues (Local Public Safety Coordinating Council 2014).

Among these organizations, several maintain close relationships with municipal and county government, as well as law enforcement. This is due largely to contracting relationships between non-profits and local governments. Portland Opportunities Industrialization Center (POIC), Latino Network, the Boys and Girls Club, and Friends of the Children all hold contracts to provide services to youth. Through these relationships, contracting institutions are able to exert greater control over policy issues than institutions that are not officially sanctioned in the same way.

\section{Law Enforcement}

Law enforcement represents only one component of the criminal justice system, which is in fact made up of police, the courts and corrections. In Multnomah County these three distinct sub-groups work closely in both the enforcement and prevention of youth and gang crimes.

Both Multnomah County courts and corrections have juvenile departments separate from their normal functions, as well as gang specific units. Multnomah County District Attorney's Office handles cases arising in the Multnomah County Juvenile Court though it's Juvenile Unit (Multnomah County District Attorney 2016a). Felony gang prosecution is handled by what known as Unit C/Gangs, started in the late 1980's and managed by ten deputy district attorneys. This unit handles all 
case brought by Portland Gang Enforcement Team, as well as all case where police make an arrest for a felony gang charge (Multnomah County District Attorney 2016a). Corrections in the form of Multnomah County's Department of Community Justice maintains a Juvenile Services division along with an Adult Services division, both of which deal with gang related induvial and work closely of policy formation and implementation through the LPSCC Youth and Gang Violence Subcommittee (Department of Community Justice 2016).

Gang enforcement in Multnomah County is made up of gang specific units at the municipal level, as well as inter-agency collaborations at the county and regional level. The most prominent gang unit operating at the municipal level is the Portland Police Bureau's Gang Enforcement Team, a unit which is nested within the Bureau's Tactical Operations Division (Portland Police Bureau 2015). A similar unit exists within the Gresham Police Department (Gresham Police Department 2016). Both of these units respond to and investigate incidents in which there is suspected gang involvement, gather intelligence on active gang members and patrol areas known to centers of gang activity (Portland Police Bureau 2015; Gresham Police Department 2016).

Many of the smaller cities in the region do not have designated gang units, but they may contribute officers to one of the regional gang enforcement collaborations. The East Multnomah Gang Enforcement Team (EMGET), which formed in 2005 after state legislators toured local gang violence hotspots, is made up of officers representing Gresham, Fairview, Troutdale, Wood Village and the Multnomah 
County Sheriff's department (Stine 2009). While EMGET focuses on the eastern parts of Multnomah County, the Metro Gang Task Force tends to operate more in the western cities and counties of the greater Portland area. Members of the Metro Gang Task Force include the Federal Bureau of Investigation (FBI), Portland Police Bureau, Beaverton Police Department, Tigard Police Department, Canby Police Department, U.S. Department of Homeland Security-Immigration and Customs Enforcement (ICE), and the U.S. Attorney's Office. These law enforcement collaborations provided support for smaller jurisdictions while generating an grater shared intelligence.

This brief cataloging of organizations and institutions involved in youth and gang violence prevention illustrates the broad emphasis on agency coordination and collaboration. The next section delves into the ways in which inter-agency coordination and collaboration have become integral to gang violence prevention in Multnomah County.

\section{Coordination and Collaboration}

Coordination and Collaboration of services and operations have become an essential approach to curbing youth and gang violence in Multnomah County and nationally. All respondents emphasized the efficiency of coordination and their desire to work in a collaborative and integrative fashion. This coordinated and collaborative approach has many similarities with strategies applied in the 1980's and 1990's, but if anything 
has become more comprehensive and totalizing. Tom Peavy of the OVYP suggests these earlier efforts did not have the same degree coordination as they now do:

"You know in the '90s you had a lot of 4-wall programming that was getting grant dollars. It was operating in their own little silo and they were providing service but there wasn't the connection that we find now. Connection's very important."

This collaborative approach has become the landscape in which differing organizations currently operate. The ethos of collaboration takes the form of the integration of efforts amongst various governmental agencies and municipalities along with non-profit service providers, and is accomplished through various means. The first being the regular meetings held throughout the county between agencies and stakeholders, specifically OYVP's bi-monthly Community Peace Collaborative meeting along with the Rockwood/Rosewood Enrichment Neighborhood Enforcement Workgroup (RENEW) meeting instituted by the Multnomah County District Attorney's Office which takes place monthly in Gresham to address that cities public safety needs, including youth and gang violence. These meetings are both ostensibly open to the public but have varying degrees of public participation. More so, there are additional confidential meetings held regularly including a Coordination Service Team meeting. Hosted by the OYVP, this meeting brings together Street Level Gang Outreach workers, Parole and Probation from both Multnomah County and the State of Oregon, and police services from Gresham, Portland, TriMet (the Portland Metro transportation agency), along with Rangers from the Portland Parks Department (Tom Peavy, personal communication, February 23, 2016). All of these 
meetings serve to connect and integrate the various services and agencies locally. Coordinated efforts have also bled over into the realm of policy creation. The LPSSC Youth and Gang Violence Subcommittee, whose current task is developing and implementing a comprehensive county-wide gang violence policy, is made up of a wide range of participants from various professional perspectives. These perspectives include those of law enforcement, public health and social services. Rebecca Stavenjord, of Multnomah County Government Relations, suggests that these differing perspectives produce an inclusive policy that addresses issues such as underlying inequalities that may otherwise be left of more traditional enforcement based initiatives (Rebecca Stavenjord, personal communication, September 15, 2016). These kinds of holistic approaches to policy are both the product of integration of differing institutional perspectives on the issue and in line with the so-called "best practices" recommended by the OJJDP.

The coordinated and collaborative approaches serve multiple functions besides simply producing greater connectivity between organizations. I identified three primary functions that coordinated and collaborative efforts achieve; an increased ability to provide services, greater control over a wider spatial area and an increased perception of legitimacy amongst the public in regards to these violence prevention efforts. 
One function identified by respondents of a coordinated and collaborative approach is an increased ability to provide services by drawing on partner organizations. The existence of multifaceted approaches to prevention alludes to the complex origins of youth and gang violence itself (Vigil 2010). Respondents frequently cited this complexity as driving the logic behind integrated approaches. Put simply, complex problems are understood to require complex solutions. Tom Peavy of the OYVP uses the metaphor of a supermarket in order to illustrate the ways in which those working to curb violence can employ various approaches and provide different services through multi-agency coordination:

"...because you have components that serve particular purposes that you can pick and choose from. It's like going to the supermarket versus trying to go to your garden and figure out what you're going to have for dinner." (Tom Peavy, personal communication, February 23, 2016)

The contracting of services through non-profits has also increased local governments ability to engage in violence prevention. Both Portland's OYVP and the City of Gresham contract gang outreach work through POIC. This same strategy has been applied by Gresham to a variety of services as explained by Gresham Gang Violence Policy Coordinator Joe Walsh:

"Our strategy has been to contract with folks like POIC, Latino Network, Boys and Girls Club, Friends of the Children to bring their services out to East County. We'll help pay for them when we can, we'll help advocate for funding at the state level or 
county level or even federal level when we can and help them help us by bringing their services out here." (Joe Walsh, personal communication, October 1, 2016)

\section{Coordination and Collaboration as Spatial Control}

As violence has shifted and the overall spatial extent of the problem has increased, coordination and collaboration between agencies and services has allowed for responsiveness over a broader area. As Fyfe (1991) illustrated police use space as divided into patrol areas and precincts in order to control people and the activity in specific places. All respondents referenced both an expanded scope of youth and gang violence, in that incidents occur throughout Multnomah County, as well as a greater mobility of individuals involved in these incidents, manifest in a back-and-forth (Eastward-Westward) pattern of movement by many gang impacted youth. Jenny Glass executive director of the Rosewood Initiative located in Gresham describes this dynamic:

“They're in here one week, and then the next week they're involved in a shooting in north Portland. It's very much connected, and it's very much something that we kind of have to consider... A lot of young people still have connections in north Portland, and are traveling back and forth a lot." (Jenny Glass, personal communication, October 6, 2015)

This pattern of movement was typically attributed to the displacement of African American families from North and North East Portland to East County and the subsequent return of gang impacted individuals to those neighborhoods where they may have extended family ties. 
One example of how multi-agency coordination and collaboration acts as a control of a broader space is the ongoing funding of the POIC Street Level Gang Outreach Workers by OVYP, the City of Gresham, Portland Parks and Recreation and TriMet. Funding for Street Level Gang Outreach in Multnomah County is provided by all of these entities. Outreach workers engage potentially gang impacted youth across the county while specifically locating themselves in areas deemed to be hotspots for violent incidents. This includes TriMet lines and several Portland Parks, hence the involvement of Parks and Recreation and TriMet as partner organizations.

Coordination and collaboration of law enforcement agencies also have meant expanded spatial control. This manifests as both informal working arrangements between agencies and more formalized partnerships with specific aims. Day-to-day collaboration between the PPB and neighboring jurisdictions often takes the form of providing assistance in crime scene management and high profile calls.

This collaboration also manifests as more formalized relationships. The East Multnomah Gang Enforcement Team (EMGET) is a partnership between the Gresham Police Department, the Multnomah County Sheriff's Office, and other east county law enforcement agencies. Their jurisdiction includes the cities of Gresham, Fairview, Troutdale, Wood Village and unincorporated areas of east Multnomah County. Their primary mission has five component strategies:

“1) provides a high level of coordinated law enforcement; 2) locates and identifies individuals affiliated with criminal street gangs; 3 ) gathers and shares intelligence 
information related to criminal street gang activity; 4) investigates crimes associated with criminal street gangs; and 5) provides an increased level of police presence in known or suspected ceremonial street gang affected areas." (East Multnomah Gang Enforcement Team 2016, 1)

Many of the strategies described above could be characterized as acting to control specific spaces and places. The designation of "known or suspected ceremonial street gang affected areas." speaks directly to the way in which law enforcement may seek to control specific behaviors through place-based policing. Additionally, the gathering of intelligence related to individuals who may be gang affiliated represents a further means of control. This kind of intelligence gathering is notoriously imprecise and frequently involve practices of indiscriminate "stopping and questioning" of young people who "fit a profile" (Bass 2001). In other parts of the country, this kind of intelligence has been used in conjunction with gang injunctions to limit the actions of individuals within certain areas. While Oregon has no gang injunction laws, regular patrol activities frequently involve removing undesirable individuals from specific areas.

Additionally, many of these groups stay connected through a relatively new communication system known as Celly. Celly is a "one text" based system similar to those used by universities to quickly and efficiently spread information via text messaging. Police, service providers, gang outreach workers, and District Attorneys rely on Celly to respond in a timely manner to developing situations. A shooting or stabbing will trigger a message distributed via the Celly system allowing law enforcement and outreach workers to congregate at a crime-scene as need be and for 
supervisors to monitor developments from afar. For gang outreach workers who spend the vast majority of their time in cars, Celly represents a particularly important means of communication.

Speaking in regards to their partnership with the City of Gresham, Tom Peavy of OYVP speaks to not only the ease of connecting different resources but the necessity of collaborative efforts given a greater spatial extent.

"They've been very compliant with the needs because you're, obviously, this is not a boundary issue dealing with gang-impacted populations. They don't recognize boundaries. We have people living in Gresham that are impacted by events that happen in Portland and people that live in Portland are impacted by events that happen and Gresham and we have to be flexible. Gresham has allowed us to work together in process on turf, so we're able to be flexible because we have this, because we have Celly and we have a team and we have all these meetings, it's easy to do that. If you had siloed programs it would be very difficult..." (Tom Peavy, personal communication, February 23, 2016)

\section{Community Participation}

Finally, the ethos of coordination and collaboration also involves an increased emphasis community participation. Many of the efforts at preventing youth and gang violence seek the participation of community members and community organizations. Multiple respondents alluded to a need for greater community involvement in the violence prevention efforts, specifically in directing these efforts. Thomas Robertson of the GIFT program states:

"You can have as many community partners, non-profits, city, state, federal, and all these organizations at the table. Unless the youth and the community themselves are 
at the table, my question is how do you truly know what somebody needs? Their wants and desires; what's the gaps missing for them?"

Some agencies are actively seeking the guidance of community. In creating questionnaires for the Multnomah County Comprehensive Gang Assessment, LPPSC's Youth and Gang Violence subcommittee solicited input from former gang members and gang involved youth, including incarcerated individuals ${ }^{14}$, as explained by Rebecca Stavenjord (Rebecca Stavenjord, personal communication, September 14, 2015).

Some initiatives were criticized by respondents as not being sufficiently guided by public input. Rosewood Initiative founder Jenny Glass describes a dynamic in which public safety initiatives may be responding to "the loudest voices" within a community.

\footnotetext{
${ }^{14}$ Rebecca Stavenjord, one of the lead authors on the Multnomah County Comprehensive Gang Assessment, offers an example of the direct involvement of gang impacted youth in the process:

"I remember talking to one young man, who, he's on paper, so he's on parole or probation. And I said, "We're testing out this tool. I wanna know where our blind spots are." I asked him to fill it out and use a highlighter and highlight the questions that made him wanna throw it back in my face. We have a close enough relationship where we can talk like that. And he did, he highlighted certain areas and there were things like in filling it out, he felt like we were extracting information instead of asking for his advice. He wanted to be a part of making his community a better place, and he felt like the survey, as it was written, was really just treating him like a gang member.'(Rebecca Stavenjord, personal communication, September 14, 2015)
} 
"Well, and what I see is like, that Gresham often responds to the loudest voices in their community, which are the empowered voices, which are the homeowners, and the middle, to upper middle class that are living in Gresham, that are concerned about the changes in their community. As a responsible person in government you want to respond to the people that are speaking out, and I guess that means not reaching out to other people that aren't speaking up. They created the community policing station in response to that part of the population's need for this problem to be addressed. They were saying, "you know what, we have these middle classes people that are really concerned about these safety issues in their community. We also have low-income people that are new to our neighborhood, and what's the answer here? We'll build a building."

She goes on,

"Yeah, I mean, what I see is that building was created with urban renewal dollars. The urban renewal dollars are allocated by government, and it's supposed to be informed by a public process, on how those funds are spent. I wasn't part of the public process that decided to spend urban renewal dollars on a new police station."'(Jenny Glass, personal communication, October 6, 2015).

One interesting outgrowth of increased community participation is Enough is Enough which is ostensibly a community-led organization, but one that is partnered with and has its origins within the OVYP and the Portland Police Bureau's Office of Community Engagement. The membership is made up largely of the friends and family of victims of gun violence. Enough is Enough is gun violence abetment program whose primary prerogatives are supporting the families of victims of gun violence and encouraging citizens with knowledge of unsolved homicides to come forward. To this point, they offer support to families through positive activities, trauma therapy and public advocacy as well a witness support group which seeks to foster relationships between affected community and law enforcement. In their materials and advocacy work, the group has adopted the acronym S.N.I.T.C.H. or 
"Somebody Needs Information That Could Help!," in an effort to re-frame what was otherwise considered a pejorative for those that would aid the efforts of law enforcement. Tom Peavy, in describing Enough is Enough is careful to separate the initiative from the OVYP.

"We are a supporter of the community-lead campaign but it's the citizens that are driving the process of Enough is Enough. They're going after their 501-C3 status now so they can hold money."

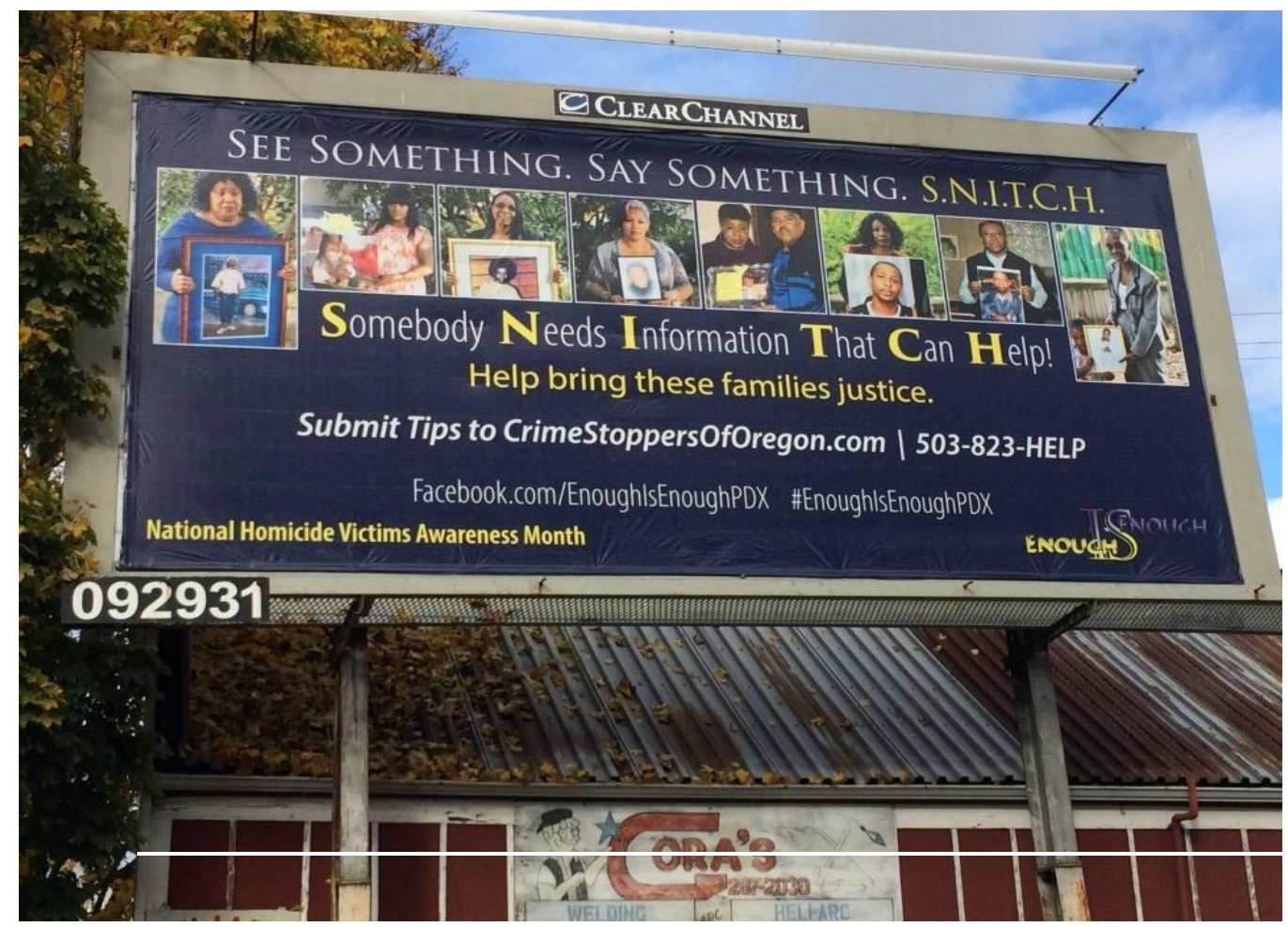

Figure 2 Enough is Enough PDX Billboard (Bernstien 2015)

This suggests a fine line that collaborations like this must walk in order to access the advantages of both of "the community", and municipal governments and law enforcement. 
This reliance on community participation does not preclude the exclusion of some voices. On March 6th, 2016 a meeting of the Community Peace Collaborative was held in advance of a visit by Attorney General Loretta Lynch to Portland. Lynch's visit was intended to highlight community policing partnerships in Portland.

However, the meeting ended abruptly when members of Don't Shoot Portland, a community group focused on police reform, raised concerns about disproportionate minority contact on the part of the Portland Police Bureau. Questions were raised as to whether Portland should be held up as an example of community policing given these ongoing issues (Bernstein 2016). Another example of this of problematic dynamic come from a LPPSC Youth and Gang

Violence Subcommittee meeting I attended on May 17th, 2015. In a discussion regarding soliciting input from community members regarding youth and police relations, law enforcement officials brought up the names of specific individual who they would not welcome working with given past interactions. This sort of selective inclusion and exclusion of community members alludes to way in which neoliberal governance tends towards a coercive use of state power by eliciting the participation of only those organizations and individuals whose practices and ideologies fall in line with the goals of the state (Wolch 1989). 


\section{Discussion}

These three primary functions of coordinated and collaborative efforts are all broadly aligned with the shifting character of urban governance under neoliberalism. Firstly, an increased ability to provide services through collaborative efforts speaks directly to Wolch's concept of the "shadow state" in which the volunteer and non-profit sector is involved in the delivery of social services previously provided by wholly public agencies (Wolch 1989). The retreat of the state as the primary provider of services, and the paradoxical expansion of over-sight and control through sub-contracting and the coercive power of grant funding and tax remittances is evident in the increased reliance on non-profits and community organizations in youth violence initiative. In Multnomah County, indirect interventions in the form of sub-contracting is especially important considering the relative lack of public awareness around the issue; local politicians are less likely to support the allocation of funds to youth and gang violence prevention as the majority of constituents are not demanding these services. Case in point, Portland Mayor Charlie Hales requested \$2 million dollars from the Portland City Council in 2015 for summer youth programs through the Parks Department. This was framed in part as an anti-youth violence initiative. However, only \$140 thousand of the original \$2 million was designated for so-called "High Risk Youth" while \$390 thousand was allocated to "General Population of Teens" (Theen 2015). It would seem that youth violence initiatives must be nested within allocations that are more widely desirable to the general population. 
Secondly, the expansion of control over a wider spatial area achieved through collaborative efforts aligns with conceptions of a neoliberalizing city in two important ways. Firstly, it alludes to the spatial disruption and reorganization characteristic of neoliberalization. As pointed out by Brenner and Theodore (2005), neoliberalism as political project inherits and reorganizes spatial configurations within urban systems, with variegated and uneven outcomes. The results of this process in Multnomah County in part explain the redistribution of violence as it is linked to suburbanizing poverty and the necessity of an expanded area of control. A second alignment comes in the form of spatial exclusion and its linkages to neoliberalization (Yarwood 2007; Herbert and Brown 2006; Beckett and Herbert 2008). The expansion of privatized space within cities and a renewed emphasis the economic value of urban space has produced a new logic of policing. As an example, while there have been multiple incidents of youth violence within the past year in and around Portland parks, most notably Holiday Park adjacent to a light rail stop and the Loyd Center Shopping Mall, locating outreach workers at these sites may have as much to do with preserving a perception of safety in public spaces of economic value. Direct funding for outreach services in these areas may, in fact, be the cause of spatially selective service provision that functions as a means to control what can and cannot happen in particular public spaces.

Finally, coordination and collaboration acts to increase a perception of legitimacy amongst the public in regards to these violence prevention efforts. Enough is Enough as a group represents an interesting example of collaboration 
between law enforcement and community, one that is clearly in line with Herbert's assertion that under neoliberal governance, community stands in for devolved authority and acts to legitimize that authority (Herbert 2006). It stands in by effectively taking on some of the investigative responsibility of the police and suggesting that the community most impacted by these crimes police itself. It also legitimizes that authority by ostensibly being "of the community" and providing a social framework that police cannot, while remaining closely tied to law enforcement. Additionally, the selective inclusion and exclusion of community members, as illustrated by the involvement of Don't Shoot Portland members in conversations around violence prevention alludes to ways in which neoliberal governance tends towards a coercive use of state power by eliciting the participation of only those organizations and individuals whose practices and ideologies fall in line with the goals of the state (Wolch 1989).

\section{Relocation}

A second primary theme to emerge from the analysis of gang violence prevention strategies is an emphasis on the re-location of social service and law-enforcement infrastructure and the creation of new forms of spatial knowledge to direct these efforts. Multiple respondents alluded to the way in which communities in East Portland lacked the kind of service provisions found in inner North and North-East 
Portland $^{15}$. The emphasis relocation is manifested in multiple ways. Most simply, this entails the establishment of physical spaces such as police stations, offices and outreach centers. It also entails the re-organization of patrol units to accommodate the redistribution of incidents of youth and gang violence. Respondents mentioned multiple service providers focused on youth and family issues that have either relocated, opened satellite offices or initiated neighborhood specific programing in East Multnomah County. The table below lists these services.

Table 1. Service Providers Mentioned by Respondents

\begin{tabular}{|llll|}
\hline & $\begin{array}{l}\text { Year of East } \\
\text { County Locating }\end{array}$ & $\begin{array}{l}\text { Physical } \\
\text { Structure }\end{array}$ & $\begin{array}{l}\text { Neighborhood } \\
\text { Specific } \\
\text { Programing }\end{array}$ \\
\hline Boys and Girls Club & 2013 & $\mathrm{x}$ & $\mathrm{x}$ \\
\hline Catholic Charities & 2010 & $\mathrm{x}$ & $\mathrm{x}$ \\
\hline Friends of the Children & 2015 & $\mathrm{x}$ & $\mathrm{x}$ \\
\hline $\begin{array}{l}\text { Latino Network Rockwood } \\
\text { Office }\end{array}$ & N/A & $\mathrm{x}$ & $\mathrm{x}$ \\
\hline Rosewood Initiative & 2012 & $\mathrm{x}$ & $\mathrm{x}$ \\
\hline Pathfinders of Oregon & 2011 & & $\mathrm{x}$ \\
\hline $\begin{array}{l}\text { POIC Rosemary Anderson } \\
\text { East }\end{array}$ & 2012 & $\mathrm{x}$ & \\
\hline
\end{tabular}

${ }^{15}$ District Attorney Eric Zimmerman explains this dynamic: “....up in North-East Portland and North Portland there's quite a bit of founded, grounded service organizations community partners that have been there forever. And stable kids know where they're at, kids' families know where they're at and know the access, someone they know knows someone who's in, who works there whereas in the east county there's a lot of need where the population is moving, a lot of those important services are still back in north-east or north." (Eric Zimmerman, August 11, 2015) 
Relocating resources or an ongoing lack of resources, has a potentially long term impact, as explained by Gresham’s Gang Violence Policy Adviser Joe Walsh,

"What's frightening is that, in a resource desert, the next group of adults is going to be less equipped to ... They're going to be more likely to be, to have to go down the gang path. They're going to be less likely to have finished school, less likely to enter the workforce, if they don't have things like a strong mentor or place to go after school, and a place where they can un-tap their potential.”(Joe Walsh, personal communication, October 1, 2016)

Law enforcement has also re-located to areas of need. The Rockwood Public Safety Facility is perhaps the most prominent example of this trend. Opened in November of 2013, the facility now houses EMGET among other public safety functions.

Combating gang violence was not a stated goal of the construction of this facility, seems to be at least an implicit goal. Quoted in The Oregonian newspaper John Bildsoe, vice president of the Coalition of Gresham Neighborhood Associations stated, "A facility like this will have a pre-emptive effect, making all but the most foolhardy wrongdoers think twice before conducting business in this part of town," (Daley 2013,n.p.) ${ }^{16}$.

\footnotetext{
${ }^{16}$ Joe Walsh argues that the Rockwood Public Safety Facility represents both an improvement in terms of public safety and as piece of community-building infrastructure: "It has this great community room. The intention there is to really, on a community grassroots level, invite folks in and say, "Hey, we're here to work with you. Rosewood Initiative, Pathfinders, Latino Network, the renewal initiative has its meetings there. All those agencies can come in and use that community space. We want folks to feel welcome, coming into a Public Safety facility. That's why we don't call it a police station, it's a public safety facility, but it's essentially a police station.
} 
The Multnomah County District Attorney's operates multiple field offices, which serve as a kind of home base for Deputy District Attorneys to work more closely within a community. The Rockwood Public Safety Facility now houses one of these offices ${ }^{17}$

Relocation, or perhaps more accurately, a spatial reorganization, has also taken on new importance in day to day policing. This is due to the fact that gangs and gang violence are no longer associated with traditional turfs as they were in previous eras.

Police have little ability to predict and locate potential hot spots and then must adapt quickly to shifting violence as it emerges. ${ }^{18}$

We want to give it a community feel. We've got that community room there on the first floor, that's open for people to use."(Joe Walsh, personal communication, October 1, 2016)

${ }^{17}$ Deputy District Attorney Eric Zimmerman explains the advantages of being cited in East County: "It makes it easier in that you're more accessible to the community. It makes it harder logistically to try and manage two caseloads, juvenile cases and adult cases that might be in the community in two places. But I'm not against it. I've noticed the importance in the rapport building that you make when you're in the community and working with the same services, better than sitting in the courthouse all day."(Eric Zimmerman, personal communication, August 11, 2015)

${ }^{18}$ Commander Dave Hendrie, East Precinct Captain and the former head of the Portland's Gang Enforcement Team states: "So in East County, the difficulty is because it's more transitory there's not a family house, so folks are less tied to any one specific location. By the time we realize this is now becoming a gang impacted area. It might have been that way for quite some time before we recognize it. It's about the dispersal of gangs through a much broader, larger area. It becomes more of a needle and a haystack approach. There's not traditional areas where you see them posted up, this is my park. That has changed dramatically which makes in my opinion policing those groups as much more difficult now than when I was a cop."(Dave Hendrie, personal communication, March 19, 2016) 


\section{Mapping}

In order to resolve the problem of diminished spatial knowledge as it relates to gang activity, the Portland Police Bureau and their Gang Enforcement Team are increasingly reliant on geo-spatial analysis to dictate the assignment of patrol. This entails the use of both single variable, hot-spot analysis which has been common amongst law enforcement agencies for some time (Yarwood 2007) and a much more complex multi-variant analysis commonly referred to as predictive policing. The PPB's Crime Analysis Unit uses so called "risk terrain models" to dictate potential patrol areas by identifying variables relating to gang crimes and associating those variables with specific areas of the city. This kind of mapping is combined with more traditional techniques that involve the anaylsis of existing data related to gang violence, e.g. shots fired calls ${ }^{19}$.

\footnotetext{
${ }^{19}$ Sgt. Greg Stewart of the Crime Analysis Unit explains this process: "You can build and you can use these risk terrain models to identify certain features that correlate with a certain prime output. In this case, gang violence. Then you identify those high risk areas, those particular features, and then you can work at mitigating the environment. Is there an environment conducive to a certain type of gang activity? We're exploring that this summer. It's a relatively new technology and we want to first build the maps, go out and look at the areas, see how it works for us. We might do something like that this summer and that's more from a reduction angle. Then we've got our historic gang analysts, who've been identifying where gang shootings are occurring and use more traditional maps to help patrol or gang team officers
} 
Mapping has also been used recently by the PPB in an effort to increase officer interactions with community members. This involves the soliciting of public input regarding particular areas within neighborhoods that may need additional patrols. These so called neighborhood involvement patrols are being folded into the work of gang officers. Over the past summer, PPB used these techniques in an initiative aimed at directed neighborhood involvement patrols, dubbed NI-Loc, which requires officers to spend 15 minutes at outside their vehicles in designated parts of the city. Sgt. Greg Stewart describes how NI-Loc is informing police responses, both specifically for gang-related crimes and more general quality of life policing:

"We had two types of responses. The gang team has a more tactical response based on their knowledge of gang members and current gang feuds and they would conduct the enforcement end because they were better informed on that. Then for the street officers, what we try to do is send them into those areas. Both at times of gang activity and at other times, to do foot patrols and really just interact with community members, with the idea that these were areas where the community was calling us a lot to anyways. Their presence will probably deter some of those calls. It'll deter some of the activity and then people in those neighborhoods would have a chance to get to know the officers also in a non-emergency situation. Ideally build some relationships before they're calling us with problems." (Greg Stewart, personal communication, February 11, 2016)

Similarly, Multnomah County has integrated so-called neighborhood indicator mapping into their processes for assessing and addressing the need for service provisions, including those meant to combat youth and gang violence. This kind of mapping of social indicators is becoming increasingly popular amongst research

determine the best areas to patrol."(Greg Stewart, personal communication, February 11, 2016) 
institutions, universities and think tanks with a goal of alleviating poverty by targeting its localized manifestations (Derikson 2007). This has been one of the key tactics deployed by LPPSC's Youth and Gang Violence Subcommittee as it prepares to implement their comprehensive plan. The authors of the study used criteria that included twenty indicators, including low-birth weight babies, births to teenage mothers, homelessness, and the use of County-funded alcohol and drug treatment services. Roberta Phillips-Robins, the Youth and Gang Violence Prevention Specialist for Multnomah County Department of Community Justice describe the reasoning behind this mapping.

"The thinking behind the whole GIS mapping was that the approach wouldn't be reactionary. We wanted to get ahead of it for the first time. What if government was actually able to be our version of nimble, which it is here with all the planning, here are all the indicators that we know contribute to gang involvement and gang violence? Now that we know that these areas have the right recipe for increased violence over the next few years, what could interventions look like if we went there? That's our version of getting ahead of things. Why not just focus on traditional areas? Because in five years that's not where we're going to see the most violence; we know that." (Roberta Phillips-Robins, personal communication, February 19, 2016)

This process has identified two key areas of need, which were mentioned frequently by respondents. These are, generally, a band of area running from outer South East Portland, north east into Gresham and the general area of the Portsmouth neighborhood along with the New Columbia housing project in North Portland. When asked whether there were additional factors that influenced the selection of these areas for targeting policy efforts, Roberta Phillips-Robins states simply, "If the map didn't show it, we wouldn't concentrate on that area." 
This mapping of social indicators conducted by Multnomah County has played a pivotal role informing the relocation of many non-profit services. Organizations serving low-income communities and those with a focus on youth and gang violence have used these maps to locate new services and satellite offices. Rebecca Stavenjord, who designed the mapping procedures, describes the reaction of organizations to this new data:

"So, we put these maps up on the wall and we showed it to about a hundred stakeholders having this conversation about what you do. And there were people in the room like Joe McFerrin from POIC, the Latino Network staff were there, Urban League, SCI, Black Parent Initiatives. There were all of these different organizations who looked at it and said, "Oh! This is the map that shows what we've been hearing from people." So they've been hearing these anecdotal experiences and haven't been able to put together the picture, the map was the picture. And then they were able to take that to the next level and say, "Okay. Well, what we need to do is open up satellite offices."(Rebecca Stavenjord, personal communication, September 14, 2015)

\section{Discussion}

As stated previously, relocation as a theme within my findings takes the form of the reconfiguration of policing and social service infrastructure, and the development of new forms of spatial knowledge guiding this relocation. At a surface level, the relocation of this infrastructure speaks to the spatial reconfigurations under neoliberalism I've discussed. These reconfigurations are seemingly guided by a common sense notion of need. However, the kind of spatial knowledge production guiding these relocations, as illustrated by Critical GIS scholars like Sarah Elwood (2002), represents both the means through which through state interest are furthered 
and legitimated and a means through which citizen groups encounter new constraints and opportunities to shape revitalization strategies. Rebecca Stavenjord alludes to these constraints and opportunities:

"So, I'm glad to see more spatial analysis being used in conversations like this. I also think that people need to understand that a map is only one part of the conversation. It's not the answer. You can very seldom find the answer in a map. It's one piece of a tool that's really a community-facilitated dialogue." (Rebecca Stavenjord, personal communication, September 14, 2015)

The degree to which various members of a community may be able to exert influence in this process, be it through mapping or otherwise, is always in question. The social indicator mapping as conducted by Multnomah County, is one illustration of how community input may direct these initiatives. In the case of PPB's NI-Loc program, the locational data provided by the public comes in the form of 911 calls, a data source that holds the potential for inherent biases. The perception of danger as experienced by a gentrifying population, may serve to direct police efforts in a way that produces further spatial exclusions for young people of color (Beckett 2012). . The use of spatial data by police in these emerging forms, as has been argued recently (Rosenblat et al. 2014) is especially problematic in that it represents a potential means through which practices of racial profiling maybe rendered legitimate through a recontextualization that emphasis space over race, while ignoring the ways in which those phenomena are entangled. 


\section{Perceptions of Gentrification}

"I don't think you can have the conversation in the city about youth violence without considering gentrification as a major factor in how it's changed in the last 20 years.”(Jenny Glass, personal communication, October 6, 2015)

Gentrification in North and North East Portland and the subsequent displacement of communities of color represents the single most impactful dynamic, as reported by respondents, to the current state of youth and gang violence in Multnomah County. Many respondents spoke at length about the impact of gentrification without prompting, often before I had the chance to begin recording an interview. Nearly every conversation at one point involved the respondent stating some version of "you must be looking at gentrification, right?" I intentionally structured questions about this issue with the greatest possible degree of neutrality. The degree to which respondents emphasized this issue speaks then to their perception of its profound impact.

Perceptions of gentrification as it pertains to youth and gang violence broke down into a single primary theme and three sub-themes. This primary theme can broadly be characterized as disruption. Disruption in this case refers to the negative impact that gentrification has had (1) on an agency's ability to functionally prevent violence through policing or service provisions (as has been alluded to earlier in this chapter), (2) the disruptive impact on existing gang structures and (3) finally the negative impacts on communities in the form of decreased agency and social cohesion. These themes overlap in many cases. Changes in gang structure (namely 
turf or lack thereof) may make prevention efforts more difficult. Similarly, diminished social cohesion may make the work of policing more difficult.

\section{Disruption of Violence Prevention Efforts}

Respondents suggested that youth and gang violence prevention efforts were frequently made more difficult by the disruptive forces of gentrification. The reasoning behind this perception in-large part relates to the difficulty experienced by respondents of effectively locating gang impacted areas and individuals and building necessary report within effected communities.

Commander Dave Hendrie describes the difficulty of identifying potential gang members given the shift away from traditionally gang impacted areas:

"What makes policing out here more difficult than when I was a younger police officer on the gang team? In the north northeast area the gang impacted families had family homes. Generational family homes. There were certain ones I can name by family name that you knew. Generations of that family name and there is certain family names that everybody knows. You knew where the house was. You knew where to find them."(Dave Hendrie, personal communication, March 19, 2016)

Commander Hendrie goes on to suggest that the lack of stable housing has a further negative impact on officers ability to locate gang involved individuals in that it increases the likelihood of officers resorting to problematic racial profiling:

"There is a group of African-American kids on the corner, but unless you know individuals or some of the other smaller cues. To look for some style of dress, some 
of the wear that they do have that kind of still identifies them slightly. It's much more understated. You really have no idea. The average patrol person won't know the difference between a group of gang impacted kids, and a group of non-gang impacted kids." (Dave Hendrie, personal communication, March 19, 2016)

In previous eras officers would have been more likely to be able to identify individuals based solely on their experience and knowledge of a given neighborhood and the individuals residing in that neighborhood.

Diminished contact with and knowledge of impacted communities has a negative impact on the work of service providers as well. The need for developing rapport with individual and communities at large was brought up my multiple respondents as was the difficulty of connecting with individuals and families in need despite the relatively robust service provisions.

The need for developing rapport with individual and communities at large was brought up my multiple respondents. Commander Hendrie describes this as being an essential piece of effective gang policing:

"You build a rapport. It's a phenomenon that most people can't grasp. Even a lot of the patrol guys that didn't do gang work don't understand it. It was almost seemed like you were friendly with these guys, because you would smile, and you'd smoke, and joke with them. You get to know the girls, the girlfriends, when they had a baby they show you a picture of the baby. You get to know their dog." (Dave Hendrie, personal communication, March 19, 2016) 
In his capacity as a commanding officer, Commander Hendrie now attempts to apply that same rapport building to the broader community within the East Precinct in an effort develop greater cohesion.

"The fight that we have is, How do I establish this precinct as a community precinct for folks that have been displaced from other areas of the city so they know hey we want that too? We want that community tightness. We want you to feel like this is your police." (Dave Hendrie, personal communication, March 19, 2016)

\section{Disruption of existing gang structures}

Respondents also mentioned ways in which gentrification and displacement adversely impact incidents of violence. This typically was understood through a dynamic in which rival gangs, forced by rising housing prices to live outside of traditional territories and many times, are increasingly living within close proximity to each other in multi-family housing in the East County.

Thomas Roberts describes this as a "chain reaction" in which historic rivalries are exacerbated by the increased likelihood of encounters between gang involved individuals.

"Minorities got pushed more eastbound into the border of Gresham area or Gresham area. The chain reaction is that you have people who don't like each other, who have that history of violence with each other, and you piled them on top of each other. In my mind, it kind of makes sense that there's that increase in violence and increase in activity in those areas, when you have people who don't like each other, people who don't get along, people who have historical backgrounds of not getting along. They're all, pretty much, living in the same areas, nearly neighbors, or a floor above each other. They're eventually going to run into each other."(Thomas Robertson, personal communication, August 14, 2015) 
The preponderance of so-called "second chance housing" housing or "felon friendly" housing in East County was also cited as compounding factor in this violence. These are generally low-income rentals that cater to ex-offenders who may not otherwise be able to secure a lease. This type of housing may put individuals and groups with existing rivalries in very close proximity ${ }^{20}$.

Territory represents an important piece of traditional gang social structures. The disruption of this structure may have an impact beyond simply putting rivals within closer proximity to each other. Tom Peavy seems to suggest that the disruption of traditional turfs may impact individual's sense of place, closely tied to one's sense of self:

"Yeah, because if you identify yourself as a Failing Block or the Woodlawn Park Bloods are identified as 68 or 6800 . Why? Dekum, 6800 block. If they're not able to live in the area that denotes their particular group, how do you think they feel? I'm no longer, if I'm a Failing Block and I'm not from Failing and I got to live out there, what am I? Do you know what I'm saying? If I'm a CVC. If I was Columbia Villa Crip and I couldn't live in the Columbia Villa any longer, what would I perceive? Why am I calling myself a CVC?” (Tom Peavy, personal communication, February 23, 2016)

\footnotetext{
${ }^{20}$ Rebecca Stavenjord suggest that second chance housing may be placed and operated with little thought given to existing social dynamics amongst residents: "they're being uprooted from traditional communities and being placed in East County where it's affordable or where there's a higher concentration of multi-family housing, a lot of that multi-family housing is second chance housing so it's felony-friendly, so we see huge concentrations of our re-entry populations with very little thought as to what your personal background or affiliation if you're involved in gangs and maybe we get placed in the same apartment complex, so then we have beef for many, many reasons.” (Rebecca Stavenjord, personal communication, September 14, 2015)
} 


\section{Disruption of Neighborhood Social Structures}

Finally and perhaps most importantly, respondents understood gentrification as representing a disruption of existing social structures within communities. This was characterized as adverse effects on a community's ability to manage gang violence, given a diminished capacity for informal social control and sense of cohesion among residents. These dynamics have been explored by several gang researchers (Hagerdon 1991; Katz and Schnebly 2008; Papachristos, et al. 2011) all of who suggest social cohesion and informal social control, as they exist at the neighborhood level can influence overall patterns of gang affiliation and crime.

Informal social control is often understood as the ability of a community to enforce norms and laws, outside of the bounds of formal control mechanisms like law enforcement (Katz and Schnebly 2008). Thomas Roberts suggest how this may look within communities with greater social cohesion:

"Like I said earlier, with no sense of community, no sense of support, or no sense of that... You know how it was with a little kid growing up. When you did something wrong, 2 blocks away, Mrs. Jackson was going to call your mom, and before you got home, your mom already knew what you did, and you're in trouble the minute you walk in the door. There's not that sense of community anymore when you spread people out, spread families out, spread support systems out. We're just seeing the repercussions of those."(Thomas Robertson, personal communication, August 14, 2015) 
Mariel Mota of the Rosewood initiative goes so far as to suggest that the diminished social cohesion has not only made it more difficult for communities to self-police, but actually furthered the conditions in which gangs might thrive:

"Gangs thrive in unhealthy neighborhoods, so where you remove community, or where people don't have community, they create them, and very often they're unhealthy. Yeah, when you shove a bunch of strangers into a neighborhood that doesn't feel like their own, they create something that's their own, and that's not always good.”.(Mariel Mota, personal communication, October 6, 2014)

New residents may also present a challenge to social cohesion in those gentrifying neighborhoods experiencing ongoing violence. Tom Peavy suggests that new residents to in North and North East neighborhoods may not be vested in tackling gang violence, despite ongoing incidents.

"We have a lot of anger based on gentrification that's never been dealt with and populations that come in here feel they have no investment in dealing with gentrification issues. Guess what? We got so many from King (neighborhood) calling us up saying, 'Hey, what are you going to do about the gang violence? It just happened. I bought a house down the street, and shoot, we got gunshots.' When I'm talking to the other police officers or people that have been around here for a long time, we're all asking each other the same question, "Where has that caller been?" This is a 30-year problem and they move in the neighborhood and they expect it to be over and they wonder why it's here. They don't have any investment in the knowledge they just want support, support in uniforms."(Tom Peavy, personal communication, February 23, 2016)

\section{Discussion}

Perceptions of the disruptive role of gentrification in my findings allude to both the spatial and social reconfigurations characteristic of the neoliberalizing city. The 
difficulty experienced by police and social service providers in locating the problem, the disruption of gang structures, and the diffusion of a once localized community all have very specific spatial conotations. The impact on the social life of those experiencing youth and gang violence, and the repurcussions for prevention of the violence, is best characterized by respondants emphasis on a deminished sense of community. Greater social cohesion or a greater "sense of community" is both an implicit and explicate goal of many of the respondents and of the initiatives discussed. The focus on increasing accessibility of service provisions through relocation, improved relationships between police and community members, the inclusion of community voices in planning initiatives, while obviously related to the "best practices" of youth and gang violence prevention, takes on a second meaning given the context of gentrification. All of these themes allude to a sense of what was lost through the destructive process of displacement. This was manifested several times through discussions in meetings and by respondent's use of the word "village" or the phase "rebuilding the village". ${ }^{21}$ In previous eras, gang violence in Multnomah County was understood as an issue of "the community" and to be resolved through the combined efforts of municipal governments and "the community" (Lindberg 1996). Implicate in that understanding was that a "community" existed in some form,

${ }^{21}$ Thomas Robertson, coordinator of GIFT program was the first in my interviews to reference the idea of a missing "village": "You hear it all the time, "It takes a village to raise a child.' Again, I go back to gentrification. Where is our village? Where is peoples' villages? Without a sense of community and village, how do you expect that child to grow?" 
even if it was weakened by structural conditions that were conducive to gang formation. In this current era, the fundamental understanding is that community ties have been severed by gentrification and that community must be rebuilt in order to effectively address the issue of youth and gang violence. 


\section{Chapter VI: Conclusion}

Over the previous chapters I have argued that the formation and proliferation of gangs is closely tied to the political economies and governance of cities. Gangs since their emergence in the United States have been rooted in spatialized inequity, forming in neighborhoods that are subject to social, economic, spatial and racial marginalization. During their first century and a half, American gangs were linked to the specific inequities produced by industrial economies. During the past forty years, Post-Fordist economic restructuring and its accompanying de-industrialization has produced new and distinct forms of gang life, including the growth of long-standing, institutionalized gangs.

Shifts within urban systems influence not only gangs, but the means through which local governments attempt to prevent and police violence. Contemporary gangprevention efforts increasingly integrate the work of both police and social service providers. The functions and practices of these institutions have shifted significantly under the influence of neoliberalization, specifically in regard to an increased responsibility for the provision of services placed on non-governmental institutions, including communities at large.

Youth and gang violence prevention in Multnomah County in the past twenty five years has both evolved and maintained many core characteristics. In the 1990's gang violence was relatively localized within the Albina area and primarily impacted the African American community. Prevention efforts were centralized within that 
community and operated with a greater degree of independence from each other, with little communication between different organizations. As violence has shifted and become more diffuse, the control efforts have done the same, becoming more collaborative, flexible and widespread, driven by new forms of spatial knowledge production. Further, these efforts are informed by a perception of gentrification and the subsequent displacement, as having a direct impact of the location and degree of violence and on the diminished ability of institutions and communities to address this violence.

In the case of Multnomah County, these findings taken as a whole illustrate a practical need to adapt to a growing and increasingly defuse geography of violence. However, characterizing these efforts solely as adaptions to a shifting landscape of violence would be misguided. These efforts also reflect broader shifts within the practice of urban governance, both locally and globally. The integration of service provision and policing as a response to gang violence not only reflects what is considered best practices within the gang control literature, but also changing philosophies and practices of policing, the transformation of welfare provisions and the valorization of collaborative governance under neoliberal regimes. Neoliberal urban governance itself plays a key role in the production of the spatial configurations impacting these geographies of violence. As illustrated by Harvey (1989), a turn toward urban entrepreneurialism meant cities have adopted an active role in attracting capital through investment in the kind of housing and infrastructure associated with the work and play of the new "creative class". The result of this process has been a 
spatial reconfiguration that has excluded many low-income communities and communities of color from the benefits of gentrification. As has been suggested by respondents, the process of gentrification itself may be negatively impacting the scale and severity of violence. Put simply then, shifts in urban governance are dictating the response to violence, while also producing the conditions within which it exists.

The data also reveals a distinctly localized character to these strategies in that they reflect both the progressive social policies that Portland and Multnomah County have become known for, as well as the racialized exclusions that are also very much a part of this city's history. This is perhaps best illustrated by respondent's emphasis on the negative impacts of gentrification and displacement, and the structural/institutional emphasis on the relocation of services and policing infrastructure. It is perhaps worth considering more closely how these seemingly contradictory themes may in fact be more closely integrated than is immediately obvious.

What is difficult to determine from the data that I have collected is the influence of day to day practices and the discretionary decisions of individual actors. The data reveals a picture of a large system of interconnected institutions and illustrates some of the ways in which these institutions interact. What it does not reveal is how the overall efficacy and impact of these strategies is the result of both carefully constructed policy formations and the actions of those individuals who conduct this work on a daily basis. As Herbert (1997) points out, an understanding of policing (and for the purposes of this study, social service provision) needs to take 
into account both the roll of the state and discretionary actions as a means through which state power is deployed. The perceptual data that I have collected provides some insight into how individuals may go about their work, but it does not provided much in a way of actual observation of this work. In order to do so, thorough ethnographic work and a close reading of that data is necessary. In that sense, this study represents a platform off of which a much richer and ethnographically focused body of research could and should be developed.

The emphasis on community solutions to youth and gang violence in a postgentrification context raises further questions. Herbert suggests that "community" can perform two functions within neoliberal governance; "it can stand in as a recipient for devolved authority, and it can legitimate that very devolution."(Herbert 2005, 852). In looking at forms of policing and service provision that emphasize the involvement and inclusion of community after gentrification, it's worth asking, what are communities being asked to do and what is being legitimatized? My response to those questions is that communities are being asked to help resolve this crisis and to legitimize the results of gentrification.

In the context of Multnomah County, the capacity of many communities to self-govern has been weakened by the process of gentrification. Communities that have been displaced and dispersed or that are emerging in parts of the county with limited resources are being asked to "rebuild" capacity, to become cohesive. Their capacity to resolve issues of youth and gang violence is limited and yet they are being 
tasked with coming together to find a solution ${ }^{22}$. Further, I believe that rebuilding as an organizing metaphor is extremely problematic. What is implied in its use is that the dispossession is complete and inarguable, that there is no recourse. When communities are asked to participate in rebuilding, they are asked to rebuild in the place, within closely defined perimeters that do not include the reclamation of urban spaces previously under their control, essentially being asked to "make due" with a situation not of their own creation. By rebuilding in place, communities are asked to legitimize their own dispossession. The movement of service provisions, the relocation of law enforcement infrastructure and an overall emphasis on East County suggest that spatial reconfiguration at the heart of this issue is in part being reified by efforts at preventing and policing youth and gang violence.

\footnotetext{
22 Jenny Glass of the Rosewood Initiative perfectly summarizes this point: "It's like, I'm trying to survive. I'm trying to feed my kids, and make it to work, or get a job, or whatever it is, so I can't worry about everybody else's problem. I can't worry about the community as a whole. I'm worried about myself. That's the type of community environment that doesn't put gang activity in check."
} 
References

Allen, N.E., 2005. A Multi-Level Analysis of Community Coordinating Councils. American journal of community psychology, 35(1-2), 49-63.

Anderson, M., and Wilson D. 2014. Urban Economic Restructuring. In Cities of North America: Contemporary Challenges in U.S. and Canadian Cities, ed. L. Benton-Short, 113-142. Lanham, MD: Rowman \& Littlefield

Avila E., and M. Rose. 2009. Race, culture, politics, and urban renewal. Journal of Urban History 35(3): 335-337.

Ball, R. A., and G.D. Curry. 1995. The logic of definition in criminology: Purposes and methods for defining "gangs". Criminology 33(2), 225-245.

Barganier III, G. P. 2011. Fanon's Children: The Black Panther Party and the Rise of the Crips and Bloods in Los Angeles. Ph.D. diss., Department of Anthropology, University of California Berkley.

Bass, S., 2001. Policing space, policing race: Social control imperatives and police discretionary decisions. Social Justice, 28(1 (83), 156-176.

Beckett, K., 2012. Race, drugs, and law enforcement. Criminology \& Public Policy, 11(4),641-653.

Beckett, K., \& Herbert, S. 2008. Dealing with disorder Social control in the postindustrial city. Theoretical Criminology 12(1): 5-30.

Bernstien, M. 2014. "Gresham mayor, police hold gang enforcement, prevention summit as summer approaches". The Oregonian. 1 May: n.p.

--- 2015. "Mothers who have lost sons to violence urge witnesses to help police solve the homicides" The Oregonian. 9 November: n.p.

--- 2016. "Meeting of community police oversight panel turns into a circus" The Oregonian. 10 June: n.p.

Berube, A. and W. Frey. 2002. A Decade of Mixed Blessings. Washington, DC: Brookings Institution.

Brenner, N., \& Theodore, N. 2002. Cities and the geographies of "actually existing neoliberalism". Antipode 34(3), 349-379. 
Blomley, N. K., and P. Rowbotham. 1996. Law, Space, and the Geographies of Power. Canadian Geographer 40(1), 88.

Brahinsky, R. 2014. Race and the making of Southeast San Francisco: Towards a theory of race-class. Antipode 46: 1258-1276

Castelles, M. 1979. The Urban Question: A Marxist Approach. Cambridge: MIT Press.

City of Gresham. 2016. Gresham Gang Prevention. Available at https://greshamoregon.gov /city/gang-prevention/default.aspx (last accessed 22 June 2016).

Coalition for a Livable Future. 2014. The Suburbanization of Poverty in the PortlandVancouver Metropolitan Region. Available at:

http://regionalequityatlas.org/programs/institutionalizing-equity/white-papers

Cooke, T.J. and Denton, C., 2015. The suburbanization of poverty? An alternative perspective. Urban Geography, 36(2), 300-313.

Cope, M. 2005. Coding Qualitative Data. In Iain Hay (ed.) Qualitative research methods in human geography. South Melbourne, Vic. New York ;: Oxford University Press.

Crawford, C.E., 2010. Spatial Policing. Durham, NC: Carolina Academic Press.

Cureton, S. R. 2008. Something wicked this way comes: A historical account of black gangsterism offers wisdom and warning for African American leadership. Journal of Black Studies. 20(5): 1-15

Curtis, A and J Mills. 2011. Crime in urban post-disaster environments: A methodological framework from New Orleans. Urban Geography 32(4): 488-510.

Daley, J. 2013. Rockwood Public Safety Facility will increase police presence in community. The Oregonian, 6 March: n.p

Davis, M. 1992. City of Quartz: Excavating the Future in Los Angeles. New York:Verso Books.

Department of Community Justice. 2016. Gang Coordination. Multnomah County, Oregon. Available at https://multco.us/dcj-adult/specialized-programs/gangcoordination (last accesed June 20 2016) 
Derickson, K. D. 2009. Gendered, material, and partial knowledges: a feminist critique of neighborhood-level indicator systems. Environment and Planning A 41(4), 896-910.

---2016. Urban geography II Urban geography in the Age of Ferguson. Progress in Human Geography, 1(15),n.p.

"DOC Research and Statistics Measure 11 Mandatory Minimum Sentencing." DOC Research and Statistics Measure 11 Mandatory Minimum Sentencing. Oregon Department of Corrections, n.d. Web. 17 Mar. 2016.

Duin, S. 2012 "Portland Gang Shootings Remain Old News at New Columbia." The Oregonian, 3 March: n.p

Elwood, S.A., 2002. GIS use in community planning: a multidimensional analysis of empowerment. Environment and planning A, 34(5), 905-922.

---2004. Partnerships and participation: Reconfiguring urban governance in different state contexts. Urban Geography, 25(8),755-770.

Esbensen, F. A., L.T. Winfree, N. He, and T.J. Taylor. 2001. Youth gangs and definitional issues: When is a gang a gang, and why does it matter? Crime \& delinquency, 47(1), 105-130.

Fyfe, N.R., 1991. The police, space and society: the geography of policing. Progress in Human Geography 15(3), 249-267.

Gibson, K. J. 2007a. Bleeding Albina: A History of Community Disinvestment, 19402000. Transforming Anthropology 15(1), 3-25.

---2007b. The Relocation of the Columbia Villa Community Views from Residents. Journal of Planning Education and Research, 27(1), 5-19.

Gilmore, R. W. 2002. Fatal couplings of power and difference: Notes on racism and geography. The Professional Geographer. 54(1),15-24.

---2007. Golden gulag: Prisons, surplus, crisis, and opposition in globalizing California. Berkley, CA: Univ of California Press

Glaze, L.E. and Keable, D., 2014. Corrections Population in the United States, 2013. NCJ, 248479.

Goetz, E., 2013. New Deal Ruins: Race, Economic Justice, and Public Housing Policy. Ithaca, NY: Cornell University Press. 
Goodling, E., Green, J. and McClintock, N., 2015. Uneven development of the sustainable city: Shifting capital in Portland, Oregon. Urban Geography, 36(4), 504527.

Elwood, S., 2004. Partnerships and participation: Reconfiguring urban governance in different state contexts. Urban Geography, 25(8), 755-770.

Hagedorn, J. M. 2006. Race not space: A revisionist history of gangs in Chicago. The Journal of African American History. 91(2): 194-208.

---2007. Gangs, Institutions, Race, and Space: The Chicago School Revisited. In Gangs in the global city: Alternatives to traditional criminology. Ed. Hagedorn, J., 13-33. Chicago, IL: University of Illinois Press

---2008. A world of gangs: Armed young men and gangsta culture. Minniapolis, MN: University of Minnesota Press.

Hagedorn, J.M. and Macon, P., 1988. People and Folks. Gangs, Crime and the Underclass in a Rustbelt City. Chicago: Lake View Press

- 2006. Race not space: A revisionist history of gangs in Chicago. The Journal of African American History, 91(2): 194-208.

-2007. Gangs, Institutions, Race, and Space: The Chicago School Revisited. In Gangs in the global city: Alternatives to traditional criminology. Ed. Hagedorn, J., 13-33. Chicago: University of Illinois Press

- 2008. A world of gangs: armed young men and gangsta culture. Minneapolis: U of Minnesota Press.

Hagerty, B. 2014. The Suburbanization of Poverty in the Portland-Vancouver Metropolitan Region. Equity White Paper Series, Coalition for a Livable Future

Hall, K. 2014. "Gangs in Gresham: Outreach worker helps at-risk youth turn around". The Oregonian 26 October: n.p.

Hall, T. and Barrett, H. 2012. Urban geography. Abingdon, UK: Routledge.

Hannah-Jones, N. 2011. "In Portland's Heart, 2010 Census Shows Diversity Dwindling." The Oregonian 30 April: n.p.

Harvey, D., 1987. Flexible accumulation through urbanization: reflections on 'postmodernism'in the American city. Antipode, 19(3), pp.260-286. 
---1989. From managerialism to entrepreneurialism: the transformation in urban governance in late capitalism. Geografiska Annaler. Series B. Human Geography, 317.

---1990. The condition of postmodernity: An enquiry into the conditions of cultural change. Oxford, UK: Blackwell

---2005. A brief history of neoliberalism. Oxford, UK: Oxford University Press

Herbert, S., 1997. Policing space: Territoriality and the Los Angeles police department. Minniapolis, MN: U of Minnesota Press.

---2005. The trapdoor of community. Annals of the Association of American Geographers, 95(4), 850-865.

---2009. Citizens, cops, and power: Recognizing the limits of community. Chicago, IL: University of Chicago Press.

Herbert, S. and Brown, E., 2006. Conceptions of space and crime in the punitive neoliberal city. Antipode, 38(4),755-777.

Hernandez, T. 2016. "Police: 4 people injured in SE Portland gang shooting". The Oregonian. 14 March.

Howell, J. C. and Moore, J. P., 2010. Office of Juvenile Justice and Delinquency Prevention. \& United States. Bureau of Justice Assistance. History of street gangs in the United States. Available at: http://purl.fdlp.gov/GPO/gpo1859 (last accessed 20 June 2016).

Jackson K (1987) Crabgrass Frontier: The Suburbanization of the United States. Oxford: Oxford University Press.

Jaquiss, N., Mesh, A. and Willson, K. 2014. “Gang Mentality”. Willamete Week, 22 July: n.p.

Katz, C.M. and Schnebly, S.M., 2008. Neighborhood variation in gang member concentrations. Crime \& Delinquency.

Kaylor,C. 2014. Portland Economic Indicators. Salem: State of Oregon Employment Department. Availible at https://www.qualityinfo.org/documents/10182/96541/Portland +Indicators? version $=1.3$ 
Klein, M. W. 1969. Violence in American juvenile gangs. Crimes of violence, 13, 1427-1460.

Klein, M.W. and Maxson, C.L., 2010. Street gang patterns and policies. Oxford, UK: Oxford University Press.

Kneebone, E. and Berube, A., 2013. Confronting suburban poverty in America. Washington, DC: Brookings Institution Press.

Lindberg, D. L. 1996. Violent youth gangs in Portland: a study of the city's response. Ph.D. diss.,Department of Urban Studies, Portland State University

Local Public Safety Coordinating Council. 2016. Youth and Gang Violence Subcommittee. Multnomah County, Oregon. Available at:

https://multco.us/lpscc/youth-and-gang-violence-subcommittee (last accessed 24 April 2016).

--- 2014. Multnomah County Comprehensive Gang Assessment. Available at: https://multco.us/lpscc/multnomah-county-comprehensive-gang-assessmen(last accessed 24 April 2016).

Lynch, M., Omori, M., Roussell, A. and Valasik, M., 2013. Policing the 'progressive'city: The racialized geography of drug law enforcement. Theoretical Criminology, 17(3),335-357.

McElderry, S. 2001. Building a West Coast Ghetto: African-American Housing in Portland, 1910-1960. The Pacific Northwest Quarterly, 92(3), p.137-148.

McGarrell, E. F., N. Corsaro, C. Melde, N.K. Hipple, T. Bynum, \& J. Cobbina. 2013. Attempting to reduce firearms violence through a Comprehensive Anti-Gang Initiative (CAGI): an evaluation of process and impact. Journal of Criminal Justice, 41(1), 33-43.

McKenzie, B. S. 2013. Neighborhood access to transit by race, ethnicity, and poverty in Portland, OR. City \& Community, 12(2), 134-155.

Miller, W. B. 1975. Violence by youth gangs and youth groups as a crime problem in major American cities. Department of Justice, Law Enforcement Assistance Administration, Office of Juvenile Justice and Delinquency Prevention, National Institute for Juvenile Justice and Delinquency Prevention. Available at://www.ncjrs.gov/pdffiles1/Digitization/34497NCJRS.pdf (last accessed June 25 2016)

---1980. Gangs, groups, and serious youth crime. Critical Issues in Juvenile Delinquency, edited by D. Schicor and D. Kelly. Lexington, MA: Lexington Books. 
Mitchell, D. 1997. The annihilation of space by law: the roots and implications of anti-homeless laws in the United States. Antipode, 29(3), 303-335.

Monmonier, M. 2006. Cartography: uncertainty, interventions, and dynamic display. Progress in Human Geography, 30(3), 373.

Moore, S., 2010. Rockwood Cultural Asset Mapping: Building Community and Engaging Residents. Available at: http://hdl.handle.net/1794/10582 (last accessed June 25 2016)

Multnomah County District Attorney. 2016. Juvenile Unit. Available at: http://mcda.us/index.php/protecting-victims-families/juvenile-matters/juvenile-unit/ (last accessed June 25 2016)

---2016. Crime Prevention and Outreach. Available at:

http://mcda.us/index.php/protecting-victims-families/crime-prevention-and-outreach/ (last accessed June 25 2016)

National Gang Center. National Youth Gang Survey Analysis. 2015. from http://www.nationalgangcenter.gov/Survey-Analysis. (last accessed June 21 2016)

Needle, J., \& Stapleton, W. V. 1983. Police handling of youth gangs. US Department of Justice, Office of Juvenile Justice and Delinquency Prevention, National Institute for Juvenile Justice and Delinquency Prevention. Available at: https://www.ncjrs.gov/App/Publications/abstract.aspx ? $\mathrm{ID}=88927$ (last accessed June 20 2016)

Office of Youth Violence Prevention. 2016. Mission. Available at: http://www.portlandonline.com/safeyouth/ (last accessed 26 June 2016).

Oregon Department of Correction. 2016. Measure 11 Mandatory Minimum Sentencing. http://www.oregon.gov/doc/RESRCH/pages/measure_11.aspx (last accessed 26 June 2016

Ozawa, C., 2004. The Portland edge: Challenges and successes in growing communities. Washington, DC: Island Press.

Papachristos, A.V., Smith, C.M., Scherer, M.L. and Fugiero, M.A., 2011. More coffee, less crime? The relationship between gentrification and neighborhood crime rates in Chicago, 1991 to 2005. City \& Community, 10(3), 215-240.

Park, C. 2015 "Last Thursday shootings: At the epicenter of Portland's changes, tensions between old and new, residents and tourists". The Oregonian. 30 May, np.

Phillips, S.A., 1999. Wallbangin': Graffiti and gangs in LA. Chicago, IL: University of Chicago Press. 
Pietila, A., 2010. Not in my neighborhood: How bigotry shaped a great American city. Lanham, MD: Ivan R. Dee.

Population Research Center. 2011. 2010 Census Profiles Oregon Cities Alphabetically MP. Available

at:https://www.pdx.edu/prc/sites/www.pdx.edu.prc/files/2010\%20SF1\%20Cities\%20M-P.pdf (Last accessed 10/21/16)

Portland Police Bureau, 2016. Archive of Monthly Data Files, 1996-2007 Available at:https://www.pdx.edu/prc/sites/www.pdx.edu.prc/files/2010\%20SF1\%20Cities\%20M-P.pdf (Last accessed 10/21/16)

Purcell, M., 2009. Resisting neoliberalization: communicative planning or counterhegemonic movements?. Planning Theory, 8(2),140-165.

---2008. Recapturing democracy: Neoliberalization and the struggle for alternative urban futures. New York, NY: Routledge.

Romo, R. 1983. East Los Angeles: History of a Barrio. Austin TX: University of Texas Press.

Rosenblat, A., Wikelius, K., Gangadharan, S.P. and Yu, C., 2014, October. Data \& Civil Rights: Criminal Justice Primer. In Data \& Civil Rights Conference, October.

Sante, L., 1991. Low life: Lures and snares of old New York. New York, NY: Macmillan.

Sassen, S. 2007. The global city: One Setting for New Types of Gang Work and Political Culture?. In Gangs in the global city: Alternatives to traditional criminology. Ed. Hagedorn, J., 97-119. Chicago, IL: University of Illinois Press

SerbuLo, L. C., \& Gibson, K. J. 2013. Black and Blue: Police-Community Relations in Portland's Albina District, 1964-1985. Oregon Historical Quarterly, 114 (1), 6-37.

Shelden, R., Tracy, S., \& Brown, W. 2013. Youth gangs in American society. Scarborough, ON: Nelson Education.

Smith, N., 1979. Toward a theory of gentrification: a back to the city movement by capital, not people. Journal of the American Planning Association, 45(4), 538-548.

---1996. The New Urban Frontier: Gentrification and the Revanchist City. Hove, UK: Psychology Press.

---2002. New globalism, new urbanism: gentrification as global urban strategy. Antipode, 34(3), 427-450.

---2010. Uneven development: Nature, capital, and the production of space. Athens, GA: University of Georgia Press. 
Spergel, I.A. and Curry, G.D. 1991. Youth gangs: Problem and response. School of Social Service Administration, University of Chicago.

Sugrue, T.1996. The Origins of the Urban Crisis: Race and Inequality in Post-War Detroit. Princeton, NJ: Princeton University Press.

Stine, M. 2009. Funds flow to gang task force. The Gresham Outlook. 30 June: n.p.

Strauss, A. and Corbin, J., 1990. Basics of qualitative research (Vol. 15). Newbury Park, CA: Sage.

Swyngedouw, E. 1997. Neither global nor local: "Glocalization" and the poltics of scale. Ed. Cox, K., Spaces of Globalization (pp 137-166). New York, NY: Guilford.

Theen, A. 2015. 1 week in, Portland's \$2 million plan to help at-risk teens off to 'booming' start. The Oregonian. 19 June:n.p

Thrasher, F. M. 1927. The gang: A Study of 1,313 Gangs in Chicago. Chicago, IL: University of Chicago Press.

Trattner, W. I. 1994. From poor law to welfare state: A history of social welfare in America (5th ed.). New York, NY: Free Press.

Vale, L. 2013. Purging the Poorest: Public Housing and the Design Politics of Twice Cleared Communities. Chicago, IL: University of Chicago Press.

Valentine, G. 1989. The geography of women's fear. Area, 21(4), 385-390.

VanderHart, D. 2013. "The Good Fight." Portland Mercury, 15 August. 2013.

---2014. We Now Know More Than Ever About Portland's Gang Violence. Will That Help Stop It?. Portland Mercury. 14 July: n.p.

---2015. "Searching for Gang Signs". Portland Mercury, 24 June. 
Venkatesh S. 2003. A Note on Social Theory and the American street gang. In, Brotherton and L. Barrios. Gangs and Society: Alternative Perspectives. New York: Columbia University Press.

Vigil, J.D. 2003. Urban violence and street gangs. Annual Review of Anthropology, 23(1) 225-242.

---2010. A rainbow of gangs: Street cultures in the mega-city. Austin, TX. University of Texas Press, 2010.

Wacquant, L., 2000. The new peculiar institution': On the prison as surrogate ghetto. Theoretical criminology, 4(3), 377-389.

---2007. Three Pernicious Premises in the Study of the American Ghetto. In Gangs in the global city: Alternatives to traditional criminology. Ed. Hagedorn, J., 34-53.

Chicago, IL: University of Illinois Press

Woods, B. 2016 "Baltimore's uprising: rival gangs push for peace after Freddie Gray's death" The Guardian. 27 April: n.p.

Wolch, J. R. 1989. The shadow state: transformations in the voluntary sector. In The Power of Geography (RLE Social \& Cultural Geography): How Territory Shapes Social Life, ed. M. Dear and J.R. Wolch,197-221. Abingdon-on-Thames: Routledge.

Wolch, J. and M. Dear. 1993. Malign Neglect. San Francisco, CA: Jossey-Bass Publishers.

Yarwood, R. 2007. The geographies of policing. Progress in human geography, 31(4), 447-465.

Yarwood, R., \& Paasche, T. 2015. The Relational Geographies of Policing and Security. Geography Compass, 9(6), 362-370. 


\section{Appendix A- Methods}

Multiple approaches were used in the course of this research. My primary data was derived from substantive interviews with gang-prevention practitioners, as well as directly observing interactions at Municipal and County sponsored public and stakeholder meetings. Participant observation was used to both identify potential respondents and to gain a better understanding of the relationships between differing organizations and parties. The goal of the analysis of the interviews and observational data was to understand the current character of gang violence prevention strategies and determine how gentrification was perceived by practitioners in relation to gang violence. By addressing these practices and perceptions, I am attempting to move beyond what I might otherwise derive solely from policy documentation. I did however rely on policy documents and media as secondary data in order to provide additional context and information that I would have otherwise been unable to gather.

Participant observation and the study site 
Over the course of roughly two years, I attended numerous meetings focused on issues of youth and gang violence in Multnomah County. Two, primary and reoccurring meetings were the source of much of my understanding and a means through which I identified my potential respondents. The first is a bi-weekly meeting sponsored and organized by the Portland Mayor's Office of Youth Violence Prevention. During the time I attended these meeting the name was changed from “Gang Violence Task Force” to “The Community Peace Collaborative”. Police officers, District Attorney's and occasionally the Mayor, present updates to the members of public and elicit support for various initiatives. Nominally, this is meant to be a way in which community members and citizen groups can voice concerns about youth and gang violence and participate in developing effective strategies to combat this violence. A second, monthly meeting sponsored by Multnomah County's Local Public Safety Coordinating Council (LPPSC), "The Youth and Gang Violence Subcommittee Meeting" has a more policy centric agenda and is not explicitly open to the public. Multnomah County is currently in the process of developing and implementing a long term gang violence strategy guided by the federal Office for Juvenile Justice Delinquency Prevention's (OJJDP) Comprehensive Gang Model. The LPPSC Youth and Gang Violence Subcommittee is therefore tasked with guiding the development of Multnomah County's policy response to gang violence. These two meetings represent two different, though related approaches to collaborative governance; one in which the perspectives of policy "experts" are emphasized, and one in which "non-experts" are invited to contribute their perspective. There is a 
significant attendance overlap between these two meetings, but in the time that I attended, I saw perhaps one or two non-affiliated "community members" attend the LPPSC meeting. It should be noted that my degree of participation occasionally veered into potentially problematic territory in terms of impacting the results of my research. While these incidents do not represent a particularly dramatic example of my participation impacting the outcome of the study, I am obligated to acknowledge my own potential influence on the people and social systems I am researching. ${ }^{23}$.

It was through the above mentioned meetings that I developed my contacts and was able to introduce myself and describe my research. I then contacted potential respondents through email and arranged interviews. Respondents were selected for their involvement in issues relating to youth and gang violence and fall into one of three categories: local government officials, law enforcement and outreach workers. I was unable to make contacts with as many respondents as I would have liked and outreach workers are under-represented in this study. To this point I relied on descriptions of outreach work provided by other respondents. The selection of respondents was purposeful and based on their involvement with efforts to prevent and enforce gang violence, however selection was opportunistic in that I followed

\footnotetext{
${ }^{23}$ On three separate occasions I was asked to provide my perspective on the wording of a particular policy document, to which I replied with a suggestion. These incidents did not produce any specific outcome or change to the document in question. On another occasion after an interview had concluded I was speaking informally with the respondent and mentioned James Diego Vigil's concept of "multiple marginality" as a framing for understanding the formation and proliferation of gangs. At a meeting a month later, I noticed that that respondent had included the term "marginality" in a draft of a document that had not previously used that term.
} 
new leads and associations as they emerged. Many of my respondents were referred to me by other respondents.

These interviews took place almost entirely at the offices of the interviewee, usually in a separate conference room. In one case I attended the arraignment of a gang involved individual on charges of attempted robbery and assault. The first interview was conducted in May of 2015 and the final was conducted in February of 2016. In total I conducted ten interviews. I developed an interview protocol based on a series of leading questions, however the interviews were semi-structured and there was considerable flexibility regarding the order and timing of questions. All interviewees read and signed the appropriate consent form, with the exception of a single respondent who agreed to have an informal discussion with me, but did not want to be recorded or have her responses included within this study.

\section{Data Analysis}

In analyzing the data collected through the interview process, I applied a thematic approach to identifying shared strategies and perspectives amongst respondents. Cope (2005) describes the main purposes of thematic coding as "data reduction, organization and the creation of searching aids, and analysis.'(Cope 2005, 223)

The process began by transcribing interview data into individual documents. Each interview was then read closely, without applying codes, with the intent of simply identifying various meanings and themes within the data. A line by line 
analysis using Deedose Qualitative Software was then conducted for each of the ten interviews, establishing initial codes. During this phase, I drew from a system devised by Strauss (Strauss and Corbin 1990) that involves searching out four primary types of themes: conditions, interactions among actors, strategies and tactics, and consequences.

Conditions in this case referred to the geographical and social context of gang violence in Portland, both currently and historically. Interactions helped establish the ways and means through which various agencies and organizations did or did not work in unison. Strategies and tactics was of special importance in that it represented my primary research question. Finally I applied initial codes referring to consequences to responses which alluded to the impact of gentrification and displacement on the broader issue of youth and gang violence.

After the first reading and the establishment of initial codes, I conducted a second reading with the intent of establishing latent codes that existed within this structure. These codes alluded to subtle differences within responses which were thematically similar. I then grouped all codes into themes, and reassessed the existing themes. This was done in order to see if the themes accurately described the codes that they were grouped with. This was a cyclic process through which I reevaluated whether existing codes fit within the themes established and which if any codes needed to be eliminated.

Table A-1 Final themes from data analysis: A

\section{Characterizing Violence Prevention Strategies}




\begin{tabular}{|l|l|l|l|}
\hline \multicolumn{1}{|c|}{ Main Theme } & \multicolumn{3}{|c|}{ Sub-Theme } \\
\hline Coordination and Collaboration & $\begin{array}{c}\text { Greater } \\
\text { ability to } \\
\text { provide } \\
\text { services }\end{array}$ & $\begin{array}{c}\text { Greater } \\
\text { Spatial } \\
\text { Control }\end{array}$ & $\begin{array}{l}\text { Community } \\
\text { Participation }\end{array}$ \\
\hline Relocation & $\begin{array}{l}\text { Relocation of } \\
\text { law } \\
\text { enforcement } \\
\text { Infrastructure }\end{array}$ & $\begin{array}{l}\text { Relocation } \\
\text { of Patrol } \\
\text { Areas }\end{array}$ & $\begin{array}{l}\text { Relocation of } \\
\text { Service } \\
\text { Infrastructure }\end{array}$ \\
\hline Production of Spatial Knowledge & $\begin{array}{l}\text { Mapping for law } \\
\text { enforcement }\end{array}$ & $\begin{array}{l}\text { Mapping for } \\
\text { Services }\end{array}$ \\
\hline
\end{tabular}

Table A-2 Final themes from data analysis: $B$

\begin{tabular}{|l|l|l|l|}
\hline \multicolumn{3}{|c|}{ Perceptions of Gentrification } \\
\hline Main Theme & \multicolumn{3}{|c|}{ Sub-Theme } \\
\hline Disruption & $\begin{array}{l}\text { Disruptive } \\
\text { to social } \\
\text { structures }\end{array}$ & $\begin{array}{l}\text { Disruptive } \\
\text { to } \\
\text { prevention } \\
\text { efforts }\end{array}$ & $\begin{array}{l}\text { Disruptive to } \\
\text { existing Gang } \\
\text { Structures }\end{array}$ \\
\hline
\end{tabular}

The results of this coding process revealed themes relating to my two primary research questions. In regard to the question of the character of gang violence prevention strategies three themes emerged: coordination and collaboration, relocation and the production of spatial knowledge. The question of practitioner's perception of gentrification revealed an additional three themes: gentrification as disruptive to social structures, gentrification as disruptive to prevention efforts and gentrification as trauma. The first group of themes can be best described as having emerged from my analysis of interactions amongst actors and their strategies and 
tactics. The second group of themes is more closely aligned with conditions and consequences. These are not hard-and-fast distinctions and bleed -over between these categories was inevitable. The resulting themes were the most predominate across the data set and are detailed in the next chapter. 
107 Hoover Criminal

111 Neighbor Hood

12th Street

13th Street Sureno

18 St Tiny Loco

18th Street

$21 \mathrm{st} \mathrm{St}$

4700 Kerby Blocc Crip

503 (White Gang)

503 Felonz

62 Diamond Crip

62 E Coast Crip

7200 North Side Gangsters

74 Hoover Criminal

79 Swans

About Our Bread

Aryan Brotherhood

Aryan Knights

Aryan Soldiers

Asian Boy Click

Bandidos

Black Star

Bloods

Boarder Brothers

Brood

Brother Speed

Brown Pride Chicanas

Brown Pride Marijuanos Trece

Campanella Prl Piru

Chinese Mafia

Columbia Villa Crip

Compton Barrios (Hispanic)

Compton Crip

Compton Piru

Compton Varrio Sequndos

Compton Varrios Tortilla Flats

Crazy Fuxxin Mexicans

Crips

Csk (Crazy Stoner Krew)

Denver Lane Blood
Dirty White Boys

E Side Wht Pride

East Side White Pride

Eight Tray Ganster Crip

Elm Lane Piru

European Kindred

Everybodys Killa

Failing Block

Family Kings - Hispanic

Family Mafia Piru

Fat Bitch Killers

Flip Side Asian

Florencia 13

Free Souls

Freemont Street 14

Fresno Bulldogs

Gangster Disciples

Gd Folks - Gangster Disciples

Ghetto Boyz Asian

Ghost Riders

Grape St Crip

Gypsy Jokers

Hammer Skinhead

Hammer Skins

Hang Out Boyz - Sureno 13

Harney Park Mob (White Gang)

Hells Angels

Hit Bitch Crew

Hmong Pride

Hoover Crip

Imperial Village Crip

Ingle Family Blood

Insane Peckerwood Syndicate

Ipo Blood - Indian Pride Org.

Irish Pride

Juggalos

Kerby Blocc Crip - 4700

Knuckleheaders White Supremacists

$\mathrm{Ku}$ Klux Klan

Laos Bloods 
Laos Cambodian Vietnamese

Latin King

Lincoln Park Blood

Loc'd Out Piru Gang

Loco Mafia Vario

Mara Salvatrucha

Method Of Destruction

Mi Vida Loca

Mob Piru

Money \& Weed

Mongols

Native Mob

Nazi Low Rider

Norteno

North Side Family

Nuk Lane Bloods

Organized Aryan Crime Syndicate

Outsiders

Paisa

Pasa Robles Boyz

Peckerwood

Pine St Clique

Playboy Gangsters (White Gang)

Playboyz

Portland Street Kids

Red Cobra

Red Cobra Bloods (Asian Gang)
Road Brothers Mc

Rockwood Krew

Rodney Blocc Hustlers

Rollin 20 Blood

Rollin 20 Crip

Rollin 30's Crip

Rollin 40 Crip

Rollin 40's Crip

Rollin 60 Crip

Sic Boys

Skinhead

Sknhds Agnst Race Prej

Sos Sons Of Samoa

Southside Trece - Surenos 13

Sur Trece Califas

Sur Trece Loco - 13 Sureno

Surena Locas

Sureno

Sureno Southside Locos

Tiny Locos Trece

Tongan Crip

Varrio Catoece

Volksfront Skin

Westside Piru

Wheels Of Soul Mc

Woodlawn Prk Bloods 


\title{
f Portland $\underset{\text { UNIVERSITY }}{\text { State }}$
}

\author{
Post Office Box $751 \quad 503-725-2227$ tel \\ Portland, Oregon 97207-0751 503-725-8170 fax \\ Human Subjects Research Review Committee \\ hsrrc@lists.pdx.edu
}

Date: March 23, 2015

To: Barbara Brower / Dirk Kinsey

From: Karen Cellarius, HSRRC Chair

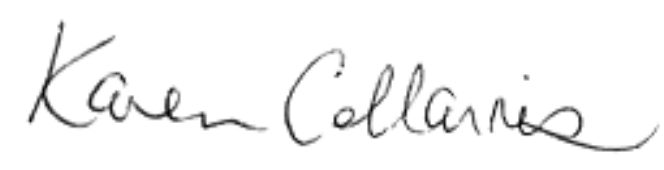

Re: $\quad$ HSRRC approval for your project titled, "Emerging Gang Geographies of Multnomah County" HSRRC Proposal \# 153319

Approval-Expiration: $\quad$ March 23, 2015 - March 22, 2016

Review Type: $\quad$ Expedited, Categories 6, 7

In accordance with your request, the PSU Human Subjects Research Review Committee has reviewed your request for approval of the project referenced above for compliance with PSU and DHHS policies and regulations covering the protection of human subjects. The Committee is satisfied that your provisions for protecting the rights and welfare of all subjects participating in the research are adequate, and your project is approved. Please note the following requirements:

Approval: You are approved to conduct this research study only during the period of approval cited above; and the research must be conducted according to the plans and protocol submitted (approved copy enclosed). 
Consent: Signed consent is required from all participants in this study.

Changes to Protocol: Any changes in the proposed study, whether to procedures, survey instruments, consent forms or cover letters, must be outlined and submitted to the Committee immediately. The proposed changes cannot be implemented before they have been reviewed and approved by the Committee.

Continuing Review: This approval will expire on 03/22/2016. It is the investigator's responsibility to ensure that a Continuing Review Report on the status of the project is submitted to the HSRRC two months before the expiration date, and that approval of the study is kept current. The IRB offices does not send out notifications of expiration dates. The Continuing Review Report is available at www.rsp.pdx.edu/compliance_human.php and in the Office of Research and Strategic Partnerships (RSP).

Adverse Reactions and/or Unanticipated Problems: If any adverse reactions or unanticipated problems occur as a result of this study, you are required to notify the Committee immediately. If the issue is serious, approval may be withdrawn pending an investigation by the Committee.

Completion of Study: Please notify the Committee as soon as your research has been completed. Study records, including protocols and signed consent forms for each participant, must be kept by the investigator in a secure location for three years following completion of the study (or per any requirements specified by the project's funding agency).

If you have questions or concerns, please contact the Office of Research Integrity in the PSU RSP at 503-725-2227. 